\title{
Probiotics, prebiotics, synbiotics and insulin sensitivity
}

\author{
Y. A. Kim, J. B. Keogh and P. M. Clifton* \\ School of Pharmacy and Medical Science and Sansom Institute for Health Research, University of South Australia, GPO Box \\ 2471, Adelaide SA 5000, Australia
}

\section{Abstract}

Animal studies indicate that the composition of gut microbiota may be involved in the progression of insulin resistance to type 2 diabetes. Probiotics and/or prebiotics could be a promising approach to improve insulin sensitivity by favourably modifying the composition of the gut microbial community, reducing intestinal endotoxin concentrations and decreasing energy harvest. The aim of the present review was to investigate the effects of probiotics, prebiotics and synbiotics (a combination of probiotics and prebiotics) on insulin resistance in human clinical trials and to discuss the potential mechanisms whereby probiotics and prebiotics improve glucose metabolism. The anti-diabetic effects of probiotics include reducing pro-inflammatory cytokines via a NF- $\mathrm{kB}$ pathway, reduced intestinal permeability, and lowered oxidative stress. SCFA play a key role in glucose homeostasis through multiple potential mechanisms of action. Activation of G-protein-coupled receptors on L-cells by SCFA promotes the release of glucagon-like peptide-1 and peptide YY resulting in increased insulin and decreased glucagon secretion, and suppressed appetite. SCFA can decrease intestinal permeability and decrease circulating endotoxins, lowering inflammation and oxidative stress. SCFA may also have anti-lipolytic activities in adipocytes and improve insulin sensitivity via GLUT4 through the upregulation of 5'-AMP-activated protein kinase signalling in muscle and liver tissues. Resistant starch and synbiotics appear to have favourable anti-diabetic effects. However, there are few human interventions. Further well-designed human clinical studies are required to develop recommendations for the prevention of type 2 diabetes with pro- and prebiotics.

\section{Key words: Probiotics: Prebiotics: SCFA: Insulin sensitivity: Clinical trials}

\section{Introduction}

The global diabetic population is rapidly growing from 382 million in 2013 to an estimated 592 million by $2035^{(1)}$. This situation imposes a great socio-economic burden on public health $^{(2)}$. Type 2 diabetes mellitus (T2DM) is a chronic metabolic disorder of abnormal glucose and lipid metabolism, resulting in CVD, retinopathy, nephropathy, neuropathy, leg ulcers and gangrene ${ }^{(3)}$. The risk factors for T2DM include obesity, age, genetics, smoking, sedentary lifestyle and hypertension $^{(2)}$. Recently, it has been proposed that changes in gut microbiota composition resulting from obesity could contribute to the pathogenesis of $\mathrm{T}_{2} \mathrm{DM}^{(4-8)}$.

Probiotics and prebiotics may exert anti-diabetic effects through changes in microbiota ${ }^{(9-13)}$. Beneficial modification of the gut flora by probiotic and/or prebiotic treatment could be one dietary therapy for the prevention and treatment of T2DM.

PubMed, EMBASE, Cochrane and Scopus online database were searched for human intervention studies using the following terms: probiotic OR fermented OR yogurt OR cheese OR prebiotic OR inulin OR fructo-oligosaccharide OR synbiotic OR resistant starch OR gut microbiota, PLUS glucose OR glycemic OR hyperglycemia OR insulin OR insulin sensitivity OR type 2 diabetes Plus Human trial. Reviews were also utilised to clarify the potential mechanisms by which probiotics, prebiotics and synbiotics may alter insulin sensitivity.

\section{Gut microbiota in individuals with type 2 diabetes mellitus} and obesity

Most gut micro-organisms inhabit the large intestine that contains an estimated $10^{11-12}$ bacteria per $\mathrm{g}^{(14)}$. Gut microbiota can influence host adiposity and regulate fat storage $e^{(4,7,15-17)}$.

The Bacteroidetes and the Firmicutes are groups of bacteria dominant in the human gut ${ }^{(8)}$. A correlation between changes in gut microbiota composition and obesity was reported in obese human subjects ${ }^{(8,18)}$ and ob/ob mice ${ }^{(19)}$, with lower microbial diversity, increased Firmicutes and decreased Bacteroidetes, and this obesity-associated gut microbiota had an increased capacity for energy harvest from the diet ${ }^{(19)}$. Germ-free wildtype $\mathrm{C} 57 \mathrm{BL} / 6 \mathrm{~J}$ mice colonised with caecal microbiota from obese donors showed a significant increase (47 (SD 8.3) \%) in body fat, compared with 27 (sD 3.6) \% in mice colonised with a

Abbreviations: AMPK, 5'-AMP-activated protein kinase; ANGPTL4, angiopoietin-like protein 4; CFU, colony-forming unit; FIAF, fasting-induced adipose factor; FFAR, free fatty acid receptor; FOS, fructo-oligosaccharide; GLP-1, glucagon like peptide-1; GPR, G-protein-coupled receptor; GPx, glutathione peroxidase; HbA1c, glycated Hb; HOMA-IR, homoeostasis model assessment for insulin resistance; IGN, intestinal gluconeogenesis; LPS, lipopolysaccharide; MCP-1, macrophage chemoattractant protein-1; PBMC, peripheral blood mononuclear cell; PYY, peptide YY; SOD, superoxide dismutase; T2DM, type 2 diabetes mellitus.

* Corresponding author: Professor Peter Clifton, fax +61 88302 2389, email Peter.Clifton@unisa.edu.au 
microbiota from lean donors over 2 weeks. During the 2 weeks, obese microbiota recipients consumed 55.4 (SD 2.5) g chow and gained $1.3(\mathrm{SD} 0 \cdot 2) \mathrm{g}$ fat, while the lean microbiota recipients consumed 54.0 (SD 1.2) g chow and gained 0.86 (SD 0.1) $\mathrm{g}$ fat, a difference of $2 \%$ of total energy consumed ${ }^{(19)}$.

Furthermore, composition of the intestinal microbiota in adults with T2DM was different from that in non-diabetic adults. The proportion of Firmicutes, Clostridia and bifidobacteria was significantly lower in diabetic adults than in non-diabetic adults ${ }^{(20,21)}$.

Mucin-degrading bacteria such as Akkermansia muciniphila and Desulfovibrio were enriched in samples derived from T2DM patients ${ }^{(22)}$. In contrast, several recent studies showed that in mice, direct administration of Akkermansia muciniphila $^{(23-27)}$ or specific proteins isolated from the outer of membrane of Akkermansia muciniphila could prevent obesity, insulin resistance as well as atherosclerosis and a human study also showed that the abundance of Akkermansia muciniphila was associated with glucose homeostasis and body fat composition $^{(28)}$.

Vrieze et $a l .{ }^{(29)}$ investigated the effect of altering the gut microbiota on insulin sensitivity in subjects with the metabolic syndrome. Obese subjects given a small-intestinal infusion of faeces from lean donors $(n 9)$ have shown improved peripheral insulin sensitivity after 6 weeks (median rate of glucose disappearance changed from $26 \cdot 2$ to $45 \cdot 3 \mu \mathrm{mol} / \mathrm{kg}$ permin; $P<0.05)$, as assessed by the two-step hyperinsulinaemiceuglycaemic clamp method. These subjects also have shown a 2.5-fold increase in butyrate-producing gut microbiota, Roseburia intestinalis, compared with obese subjects reinfused with their own faeces ( $n$ 9). The faecal microbiota of obese subjects had lower microbial diversity, and contained higher amounts of Bacteroidetes and lower amounts of Clostridium cluster XIVa compared with faecal microbiota after lean donor infusion at 6 weeks ${ }^{(29)}$.

Germ-free mice which are protected from diet-induced obesity had increased phosphorylated 5'-AMP-activated protein kinase (AMPK) in skeletal muscle and liver and increased fatty acid oxidation enzymes (acetyl CoA carboxylase; carnitine palmitoyltransferase), while germ-free knockout mice deficient in fastinginduced adipose factor (FIAF), a circulating lipoprotein lipase inhibitor, were not resistant to diet-induced obesity. Germ-free FIAF-deficient animals fed a Western diet showed decreased expression of the peroxisomal proliferator activated receptor- $\gamma$ coactivator $1 \alpha$ (PGC1 $\alpha)$ which is known to increase genes encoding regulators of mitochondrial fatty acid oxidation in the gastrocnemius muscle compared with germ-free $\mathrm{FIAF}^{+/+}$littermates, while there were no differences in phosphorylated AMPK levels between both groups. Consequently, germ-free mice were protected from diet-induced obesity through increased FIAF by inducing PGCl $\alpha$ and also through elevated AMPK activity, implicating that obese gut microbiota can be responsible for decreased fatty acid oxidation and decreased FIAF/AMPK within the adipose tissue and liver ${ }^{(30)}$

The lipopolysaccharide (LPS) endotoxins, found in the outer membrane of some species of Gram-negative bacteria (for example, Neisseria spp. and Haemophilus spp.), induce signalling by binding to Toll-like receptor-4 present on endothelial cells, macrophages and monocytes. This promotes pro-inflammatory cytokines, chemokines, adhesion molecules and reactive oxygen species. An increase in LPS has been directly associated with insulin resistance ${ }^{(31)}$. Cani et al. ${ }^{(32)}$ found in a mouse model that high-fat feeding changes gut microbiota with a marked reduction in some bacteria (Lactobacillus spp. and Bacteroides-Prevotella spp.), leading to an increased intestinal permeability, and LPS absorption. This increased metabolic endotoxaemia initiates adipose tissue inflammation (plasminogen activator inhibitor-1 and IL-1 mRNA), macrophage infiltration markers (macrophage chemoattractant protein-1 (MCP-1) mRNA, F4/80 mRNA) and oxidative stress (NADPHox mRNA, visceral adipose tissue and six transmembrane protein of prostate 2 (STAMP2, known to regulate nutrient-derived and inflammatory signals coordinately for metabolic homeostasis $\left.{ }^{(33,34)}\right)$ ).

Even though intestinal microbiota may play a role in the aetiology of obesity and insulin resistance, the relationship between the bacteria and these metabolic disorders remains a matter of debate and most publications merely report associations between intestinal microbial composition and metabolic disorders such as obesity and $\mathrm{T}_{2} \mathrm{DM}^{(35)}$.

Probiotics and effects of probiotics on glucose metabolism in human interventions

According to the $\mathrm{FAO} / \mathrm{WHO}$, probiotics are live microorganisms which, when administered in adequate amounts, confer a health benefit on the host' ${ }^{(36)}$. The requirement of adequate amounts differs between countries: products must contain at least $10^{7}$ colony-forming units (CFU)/g of probiotic bacteria in Japan, at least $10^{8} \mathrm{CFU} / \mathrm{g}$ probiotic bacteria in USA and $10^{9} \mathrm{CFU} / \mathrm{g}$ probiotic bacteria in Canada. In general, $>10^{6}-10^{8} \mathrm{CFU} / \mathrm{g}$, or $>10^{8}-10^{10}$ $\mathrm{CFU} / \mathrm{d}$ of viable cells are regarded efficacious ${ }^{(37,38)}$, but the cell count levels recognised do not guarantee a health effect ${ }^{(38,39)}$. Moreover, it is suggested that the recommendation for $\mathrm{CFU}$ determination should be established using accurate and frequent assessments because the number of viable cells is reduced during production, processing and formulation ${ }^{(38)}$.

Some of the species are: (1) lactic acid-producing bacteria (Lactobacillus, Bifidobacterium, Streptococcus); (2) non-lactic acid-producing bacterial species (Bacillus, Propionibacterium); (3) non-pathogenic yeasts (Saccharomyces; for example, Saccharomyces boulfecesardii, a non-colonising lactic acidproducing yeast); (4) non-spore-forming and non-flagellated rod or coccobacilli ${ }^{(40)}$. Over 100 Lactobacillus and over thirty Bifidobacterium species have been identified ${ }^{(40)}$. Lacticproducing Bifidobacterium and Lactobacillus are the predominant and subdominant probiotic groups ${ }^{(41)}$.

Human interventions with probiotics are shown in Table 1. Ten interventions ${ }^{(10,12,42-49)}$ have shown positive effects of probiotics on glucose control. Ten interventions ${ }^{(6,50-58)}$ have shown no effect and two interventions have shown negative effects ${ }^{(59)}$.

Patients with T2DM supplemented with probiotic yogurt experienced attenuated fasting glucose and glycated $\mathrm{Hb}$ (HbA1c) concentrations and increased erythrocyte superoxide dismutase (SOD), glutathione peroxidase (GPx) activities and total antioxidants, compared with the control group ${ }^{(10)}$. Pregnant women given a probiotic supplement (Bifidobacterium lactis Bb12 and 
Table 1. Summary of probiotic human intervention studies

\begin{tabular}{|c|c|c|c|c|c|c|c|}
\hline Type & Probiotic stains and dose used & Design & Subjects & Period & Outcomes & No effects & Reference \\
\hline Drink & $\begin{array}{l}400 \mathrm{ml} / \mathrm{d} \text { of a rose-hip drink containing Lactobacillus plantarum } 299 \mathrm{v} \\
\left(5 \times 10^{7} \mathrm{CFU} / \mathrm{ml}\right) \mathrm{v} .400 \mathrm{ml} / \mathrm{d} \text { of a rose-hip drink without bacteria }\end{array}$ & $C, P C, P, R D, D B$ & $\begin{array}{l}36 \text { Healthy smokers aged } \\
35-45 \text { years } \\
\text { Treatment }(n 18) \\
\text { Control }(n 18)\end{array}$ & 6 weeks & $\begin{array}{l}\downarrow \text { SBP, fibrinogen and } \\
\text { IL-6 within the } \\
\text { treatment group } v \text {. } \\
\text { baseline }\end{array}$ & $\begin{array}{l}\text { Glucose, insulin, BMI, } \\
\text { BP, lipids }\end{array}$ & $\begin{array}{l}\text { Naruszewicz } \\
\text { et al. } \\
\quad(2002)^{(50)}\end{array}$ \\
\hline Yogurt & $\begin{array}{l}\text { Low-fat yogurt of } 100 \mathrm{ml} / 3 \times \mathrm{d} \text { containing Streptococcus thermophilus } \\
\text { and } L \text {. delbrueckii subsp. bulgaricus plus } \\
B \text {. Iongum BL } 1 \mathrm{v} \text {. low-fat yogurt of } 100 \mathrm{~m} / 3 \times \mathrm{d} \text { containing } \\
\text { S. thermophilus and } L \text {. delbrueckii subsp. bulgaricus }\end{array}$ & $\mathrm{RD}, \mathrm{PC}, \mathrm{SB}, \mathrm{P}$ & $\begin{array}{l}32 \text { Adults with TC ranging from } \\
220 \text { to } 280 \mathrm{mg} / \mathrm{dl}(5.7 \text { to } \\
7.3 \mathrm{mmol} / \mathrm{l}) \\
\text { Treatment }(n 16) \\
\text { Control }(n 16)\end{array}$ & 4 weeks & $\downarrow \mathrm{TC}, \downarrow$ LDL-C,$\downarrow$ TAG & Glucose & $\begin{array}{l}\text { Xiao et al. } \\
(2003)^{(51)}\end{array}$ \\
\hline Capsule & $\begin{array}{l}\text { Freeze-dried capsule }\left(2 \times 10^{9} \mathrm{CFU} / \text { tablet }\right) \text { containing } \\
\text { L. fermentum v. placebo twice daily }\end{array}$ & $\mathrm{DB}, \mathrm{PC}, \mathrm{P}$ & $\begin{array}{l}44 \text { Subjects with } \mathrm{HC} \text { aged } \\
30-75 \text { years } \\
\text { Treatment }(n 23) \\
\text { Placebo }(n 21)\end{array}$ & 10 weeks & & $\begin{array}{l}\text { Glucose, TC, HDL-C, } \\
\text { LDL-C, TAG }\end{array}$ & $\begin{array}{l}\text { Simons et al. } \\
(2006)^{(52)}\end{array}$ \\
\hline Capsule & $\begin{array}{l}\text { (a) Diet supplemented with probiotics containing L. rhamnosus } \\
\text { GG and Bifidobacterium lactis Bb12 dietary counselling } \\
\text { (b) Diet/placebo } \\
\text { (c) Placebo }\end{array}$ & $\mathrm{RD}, \mathrm{P}, \mathrm{DB}, \mathrm{PC}$ & $\begin{array}{l}196 \text { Pregnant women aged } \\
25-35 \text { years } \\
\text { (a) }(n 66) \\
\text { (b) }(n 70) \\
\text { (c) }(n 60)\end{array}$ & 20 weeks & $\begin{array}{l}\downarrow \text { Glucose, } \downarrow \text { insulin, } \\
\downarrow \downarrow \text { HOMA }, \uparrow \text { QUICKI }\end{array}$ & $\mathrm{HbA} 1 \mathrm{c}$ & $\begin{array}{l}\text { Laitinen et al. } \\
\qquad(2009)^{(42)}\end{array}$ \\
\hline Capsule & $\begin{array}{l}\text { Capsule with freeze-dried L. acidophilus (NCFM - ATCC } 700396 \\
\left(1 \mathrm{~g} ; \text { about } 10^{10} \mathrm{CFU}\right) \text { ) v. placebo (a mixture of silicon dioxide and lactose, } \\
\text { ratio 1:1) }\end{array}$ & $\mathrm{RD}, \mathrm{P} \mathrm{DB}, \mathrm{PC}$ & $\begin{array}{l}45 \text { Males } \\
\text { Treatment }(n 21,10 \mathrm{NGT} \text {, } \\
3 \text { IGT and } 8 \text { T2DM) } \\
\text { Placebo ( } n 24,12 \mathrm{NGT} \text {, } \\
2 \text { IGT and } 10 \text { T2DM) }\end{array}$ & 4 weeks & $\begin{array}{l}\uparrow \text { Insulin sensitivity by } \\
\text { hyperinsulinaemic- } \\
\text { euglycaemic clamp }\end{array}$ & $\begin{array}{l}\text { TNF-a, IL-6, IL-Ira, } \\
\text { hs-CRP }\end{array}$ & $\begin{array}{l}\text { Andreasen } \\
\text { et al. } \\
\quad(2010)^{(43)}\end{array}$ \\
\hline Capsule & $\begin{array}{l}2.9 \times 10^{9} \mathrm{CFU} \text { of } L \text {. reuteri NCIMB } 30242 \text { capsule } v \text {. placebo maltodextrin } \\
\text { capsule twice daily }\end{array}$ & $\mathrm{DB}, \mathrm{PC}, \mathrm{P}$ & $\begin{array}{l}124 \text { Adults with HC } \\
\text { Treatment }(n 62) \\
\text { Placebo }(n 62)\end{array}$ & 9 weeks & & Fasting glucose, BMI & $\begin{array}{l}\text { Jones et al. } \\
\quad(2012)^{(53)}\end{array}$ \\
\hline Yogurt & $\begin{array}{l}300 \mathrm{~g} / \mathrm{d} \text { of yogurt containing } L \text {. acidophilus La5, B. lactis Bb12 with dose of } \\
3.98 \times 10^{9} \mathrm{CFU} v \text {. conventional yogurt }\end{array}$ & $\mathrm{RD}, \mathrm{P}, \mathrm{DB}, \mathrm{PC}$ & $\begin{array}{l}60 \text { Patients with T2DM aged } \\
30-60 \text { years, BMI }<35 \mathrm{~kg} / \mathrm{m}^{2} \\
\text { Treatment }(n 30) \\
\text { Control }(n 30)\end{array}$ & 6 weeks & $\begin{array}{l}\downarrow \text { Fasting glucose, } \\
\quad \downarrow \text { HbA1c, } \\
\quad \uparrow \text { antioxidant status }\end{array}$ & Insulin & $\begin{array}{l}\text { Ejtahed et al. } \\
(2012)^{(10)}\end{array}$ \\
\hline Capsule & $10^{10} \mathrm{CFU}$ of L. salivarius Ls-33 v. placebo daily & $\mathrm{RD}, \mathrm{PC}, \mathrm{DB}, \mathrm{P}$ & $\begin{array}{l}50 \text { Obese adolescents aged } \\
12 \text { to } 15 \text { years } \\
\text { Treatment }(n 27) \\
\text { Placebo }(n 23)\end{array}$ & 12 weeks & & $\begin{array}{l}\text { Fasting glucose, insulin, } \\
\text { HOMA-IR, C-peptide, } \\
\text { TC, TAG, NEFA, hs-CRP, } \\
\text { IL-6, TNF-a }\end{array}$ & $\begin{array}{l}\text { Gøbel et al. } \\
\quad(2012)^{(57)}\end{array}$ \\
\hline Capsule & $\begin{array}{l}1500 \mathrm{mg} \text { probiotic capsule containing } L \text {. acidophilus, } L \text {. bulgaricus, } \\
\text { L. bifidum and } L \text {. casei twice daily } v .1500 \mathrm{mg} \text { placebo capsule containing } \\
1000 \mathrm{mg} \text { magnesium stearate twice daily }\end{array}$ & $\mathrm{SB}, \mathrm{PC}, \mathrm{P}$ & $\begin{array}{l}34 \text { Subjects with T2DM } \\
\text { Treatment }(n 16) \\
\text { Placebo }(n 18)\end{array}$ & 6 weeks & & $\begin{array}{l}\text { Glycaemic control, lipids, } \\
\text { inflammatory markers }\end{array}$ & $\begin{array}{l}\text { Yousefinejad } \\
\text { et al. } \\
(2013)^{(54)}\end{array}$ \\
\hline Capsule & $\begin{array}{l}\text { Capsule containing } 10^{10} \mathrm{CFU} \text { L. gasseri BNR17 and filler powder ( } 50 \% \\
\text { trehalose, } 25 \% \text { skimmed milk, and } 25 \% \text { FOS) v. placebo capsule } \\
\text { containing filler powder. Six capsules per d taken }\end{array}$ & $\mathrm{RD}, \mathrm{PC}, \mathrm{DB}, \mathrm{P}$ & $\begin{array}{l}50 \text { Obese adults with } \\
\text { BMl } \geq 23 \mathrm{~kg} / \mathrm{m}^{2} \\
\text { Treatment }(n 22) \\
\text { Placebo }(n 28)\end{array}$ & 12 weeks & & $\begin{array}{l}\text { Fasting glucose, insulin, } \\
\text { BMI }\end{array}$ & $\begin{array}{l}\text { Jung et al. } \\
\quad(2013)^{(55)}\end{array}$ \\
\hline Cheese & $\begin{array}{l}\text { Hypoenergetic diet }(1512 \mathrm{kcal} ; 6326 \mathrm{~kJ}) \text { supplemented with } 50 \mathrm{~g} \text { probiotic } \\
\text { cheese made with } L \text {. plantarum TENSIA added to the cheese milk in } \\
\text { amounts of } 1.5 \times 10^{11} \mathrm{CFU} / \mathrm{g} \text { before renneting } \mathrm{v} .50 \mathrm{~g} \text { control Edam-type } \\
\text { cheese made with a starter C92. } 50 \mathrm{~g} \text { of each cheese was } 175 \mathrm{kcal} \\
(732 \mathrm{~kJ})\end{array}$ & $R D, D B, P C, P$ & $\begin{array}{l}36 \text { Obese hypertensive } \\
\text { subjects } \\
\text { Treatment }(n \text { 25) } \\
\text { Control }(n 11)\end{array}$ & 3 weeks & $\downarrow \mathrm{BMI}, \downarrow \mathrm{BP}$ & Glucose, lipids & $\begin{array}{l}\text { Sharafedtinov } \\
\text { et al. } \\
(2013)^{(56)}\end{array}$ \\
\hline Yogurt & $\begin{array}{l}\text { Probiotic yogurt of } 200 \mathrm{~g} / \mathrm{d} \text { containing } S \text {. thermophilus, } L \text {. bulgaricus, } \\
\text { L. acidophilus LA5 and B. animalis BB12 with dose } \\
\text { of } 1 \times 10^{7} \mathrm{CFU} v \text {. conventional yogurt of } 200 \mathrm{~g} / \mathrm{d} \text { containing } \\
\text { only starter cultures of } S \text {. thermophilus and } L \text {. bulgaricus }\end{array}$ & $\mathrm{RD}, \mathrm{SB}, \mathrm{PC}, \mathrm{P}$ & $\begin{array}{l}70 \text { Primigravida pregnant } \\
\text { women with singleton } \\
\text { pregnancy at their third } \\
\text { trimester } \\
\text { Treatment }(n 37) \\
\text { Control }(n 33)\end{array}$ & 9 weeks & $\downarrow$ Insulin, $\downarrow$ HOMA & Fasting glucose, BP & $\begin{array}{l}\text { Asemi et al. } \\
(2013)^{(45)}\end{array}$ \\
\hline Yogurt & $\begin{array}{l}300 \mathrm{~g} / \mathrm{d} \text { of probiotic yogurt containing a total of } L \text {. delbrueckii subsp. } \\
\text { bulgaricus, } S \text {. thermophilus. B. animalis subsp. lactis Bb12 and } \\
L \text {. acidophilus La5 with dose of } 1.11 \times 10^{9} \mathrm{CFU} / \mathrm{d} v \text {. } 300 \mathrm{~g} / \mathrm{d} \text { conventional } \\
\text { yogurt containing } L \text {. delbrueckii subsp. bulgaricus and } \\
\text { S. thermophilus }\end{array}$ & $\mathrm{RD}, \mathrm{P}, \mathrm{DB}, \mathrm{PC}$ & $\begin{array}{l}40 \text { Obese adults with T2DM, } \\
\text { BMI } \geq 25 \mathrm{~kg} / \mathrm{m}^{2} \\
\text { Treatment }(n 20) \\
\text { Control }(n 20)\end{array}$ & 8 weeks & $\begin{aligned} \downarrow & \text { HbA1c, } \downarrow \text { TNF- }, \\
& \downarrow \text { hs-CRP, } \downarrow \text { IL- } 6\end{aligned}$ & Glucose & $\begin{array}{l}\text { Mohamadshahi } \\
\quad \text { et al. } \\
(2014)^{(44)}\end{array}$ \\
\hline
\end{tabular}




\begin{tabular}{|c|c|c|c|c|c|c|c|}
\hline Type & Probiotic stains and dose used & Design & Subjects & Period & Outcomes & No effects & Reference \\
\hline Capsule & $\begin{array}{l}\text { Probiotic capsule containing L. salivarius with dose of } \\
1 \times 10^{9} \mathrm{CFU} / \mathrm{d} v \text {. placebo capsule }\end{array}$ & $\mathrm{DB}, \mathrm{PC}, \mathrm{RD}, \mathrm{P}$ & $\begin{array}{l}138 \text { Pregnant obese women } \\
\text { with mean BMI } 33 \cdot 6 \mathrm{~kg} / \mathrm{m}^{2} \\
\text { Treatment }(n 63) \\
\text { Placebo }(n 75)\end{array}$ & 4 weeks & & $\begin{array}{l}\text { Fasting glucose, insulin, } \\
\text { HOMA-IR, lipids, hs- } \\
\text { CRP }\end{array}$ & $\begin{array}{l}\text { Lindsay et al. } \\
\qquad(2014)^{(6)}\end{array}$ \\
\hline $\begin{array}{r}\text { Capsule/ } \\
\text { yogurt }\end{array}$ & $\begin{array}{l}\text { (a) Probiotic yogurt + probiotic capsules } \\
\text { (b) Probiotic yogurt + placebo capsules } \\
\text { (c) Control milk + probiotic capsules } \\
\text { (d) Control milk + placebo capsules } \\
\text { Probiotic yogurt and a probiotic capsule contained L. acidophilus La5 } \\
\text { and B. animalis subsp. lactis Bb12 with dose of } 3.0 \times 10^{9} \mathrm{CFU} / \mathrm{d}\end{array}$ & $\mathrm{DB}, \mathrm{P}, \mathrm{PC}$ & $\begin{array}{l}156 \text { Overweight adults aged } \\
\text { over } 55 \text { years (mean: } 67 \pm \\
8 \text { years old) } \\
\text { (a) }(n 40) \\
\text { (b) }(n 37) \\
\text { (c) }(n 39) \\
\text { (d) }(n 40)\end{array}$ & 6 weeks & $\begin{array}{l}\uparrow \text { HOMA-IR in probiotic } \\
\text { yogurt, } \uparrow \text { fasting } \\
\text { glucose in probiotic } \\
\text { capsules }\end{array}$ & Insulin, $\mathrm{HbA} 1 \mathrm{c}$ & $\begin{array}{l}\text { Ivey et al.. } \\
\quad(2014)^{(59)}\end{array}$ \\
\hline Capsule & $\begin{array}{l}\text { 12.5 } \times 10^{9} \mathrm{CFU} / \text { capsule VSL } \# 3 \text { containing B. longum, B. infantis, } \\
\text { B. breve, L. acidophilus, L. paracasei, L. delbrueckii subsp. bulgaricus, } \\
\text { L. plantarum and S. salivarius subsp. thermophilus v. } n-3 \text { capsules } \\
\text { V. } n-3+\text { VSL\#3 v. placebo (cellulose) }\end{array}$ & $\mathrm{RD}, \mathrm{DB}, \mathrm{PC}, \mathrm{P}$ & $\begin{array}{l}60 \text { Overweight }(\mathrm{BMl}>25 \mathrm{~kg} / \\
\left.\mathrm{m}^{2}\right) \text {, healthy adults, aged } \\
40-60 \text { years } \\
\text { Treatment } 1(n \text { 15) } \\
\text { Treatment } 2(n 15) \\
\text { Placebo }(n \text { 15) }\end{array}$ & 6 weeks & $\begin{array}{l}\downarrow \text { Lipids, } \downarrow \text { HOMA, } \\
\uparrow \text { hsCRP within } \\
\text { VSL\#3 and VSL\#3 + } \\
n-3 \text { groups } v \text {. } \\
\text { baselines } \\
\uparrow \text { Lactobacilli and } \\
\text { bifidobacteria in a } \\
\text { VSL\#3 group }\end{array}$ & & $\begin{array}{l}\text { Rajkumar et al. } \\
(2014)^{(46)}\end{array}$ \\
\hline Yogurt & $\begin{array}{l}80 \mathrm{ml} / \mathrm{d} \text { of fermented milk with L. plantarum }\left(1.25 \times 10^{7} \mathrm{CFU} / \mathrm{g}\right) \mathrm{v} .80 \mathrm{ml} / \mathrm{d} \text { of } \\
\text { non-fermented milk }\end{array}$ & $\mathrm{SB}, \mathrm{PC}, \mathrm{P}$ & $\begin{array}{l}24 \text { Postmenopausal women } \\
\text { with the MetS } \\
\text { Treatment }(n 12) \\
\text { Placebo }(n 12)\end{array}$ & $90 d$ & $\begin{array}{l}\downarrow \text { Fasting glucose, } \\
\downarrow \text { homocysteine }\end{array}$ & Insulin, HOMA-IR & $\begin{array}{l}\text { Barreto et al. } \\
\quad(2014)^{(49)}\end{array}$ \\
\hline Yogurt & $\begin{array}{l}200 \mathrm{~g} / \mathrm{d} \text { of fermented milk with } 5 \times 10^{10} \mathrm{CFU} / 100 \mathrm{~g} \text { of } L \text {. gasseri SBT2055 } \\
\text { (LG2055) v. fermented milk without LG2055 }\end{array}$ & SB, PC,P & $\begin{array}{l}20 \text { Subjects with } \\
\text { hypertriacylglycerolaemia }\end{array}$ & 4 weeks & $\begin{array}{l}\uparrow \text { HbA1c, } \downarrow \\
\text { postprandial and } \\
\text { fasting serum NEFA } \\
\text { levels }\end{array}$ & & $\begin{array}{l}\text { Ogawa et al. } \\
(2014)^{(58)}\end{array}$ \\
\hline Yogurt & $\begin{array}{l}600 \mathrm{ml} / \mathrm{d} \text { of probiotic fermented milk containing L. casei, L. acidophilus and } \\
\text { bifidobacteria with dose of } 3.4 \times 10^{9} \mathrm{CFU} / \mathrm{d} \text { (at day 21) v. } 600 \mathrm{ml} / \mathrm{d} \text { of } \\
\text { placebo conventional fermented milk }\end{array}$ & RD, P, DB, PC & $\begin{array}{l}60 \text { Diabetic patients aged } \\
35-65 \text { years } \\
\text { Treatment }(n 30) \\
\text { Placebo }(n 30)\end{array}$ & 8 weeks & $\begin{array}{l}\downarrow \text { HbA1c, } \downarrow \text { fasting } \\
\text { glucose }\end{array}$ & TAG, TC, LDL-C, HDL-C & $\begin{array}{l}\text { Ostadrahimi } \\
\text { et al. } \\
(2015)^{(47)}\end{array}$ \\
\hline Yogurt & $300 \mathrm{ml}$ of Cardi04 yogurt containing L. helveticus once daily & RD, P, DB, PC & $\begin{array}{l}41 \text { Patients with T2DM } \\
\text { Treatment }(n \text { 23) } \\
\text { Placebo }(n 18)\end{array}$ & 12 weeks & $\downarrow$ Fasting glucose & $\begin{array}{l}\text { HbA1c, lipids, hs-CRP, } \\
\text { TNF-a }\end{array}$ & $\begin{array}{l}\text { Hove et al. } \\
\quad(2015)^{(12)}\end{array}$ \\
\hline Capsule & $\begin{array}{l}\text { Probiotic capsule containing three viable freeze-dried strains including } \\
\text { L. acidophilus }\left(2 \times 10^{9} \mathrm{CFU} / \mathrm{g}\right), \text { L. casei }\left(2 \times 10^{9} \mathrm{CFU} / \mathrm{g}\right) \text { and B. bifidum } \\
\left(2 \times 10^{9} \mathrm{CFU} / \mathrm{g}\right) \text { v. placebo (cellulose) once daily }\end{array}$ & $\mathrm{RD}, \mathrm{P}, \mathrm{DB}, \mathrm{PC}$ & $\begin{array}{l}\text { Primigravida } 60 \text { pregnant } \\
\text { women with gestational } \\
\text { diabetes aged } 18-40 \text { years } \\
\text { Treatment }(n 30) \\
\text { Placebo }(n 30)\end{array}$ & 6 weeks & $\begin{array}{l}\downarrow \text { Fasting glucose, } \\
\quad \downarrow \text { insulin, } \downarrow \text { HOMA- } \\
\text { IR, } \\
\downarrow \text { HOMA for } \\
\beta \text {-cell function, } \\
\quad \uparrow \text { QUICKI, } \downarrow \text { TAG, } \\
\downarrow \text { VLDL-C }\end{array}$ & & $\begin{array}{l}\text { Karamali et al. } \\
(2016)^{(48)}\end{array}$ \\
\hline
\end{tabular}

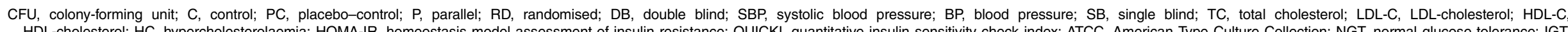

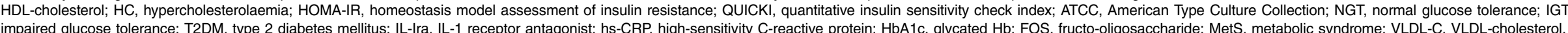


Lactobacillus rhamnosus GG) and dietary counselling together had improved glycaemic control during and after pregnancy compared with the control/placebo group ${ }^{(42)}$.

In sixty women with gestational diabetes, the daily supplement of a probiotic capsule, containing three viable freeze-dried strains including Bifidobacterium bifidum $\left(2 \times 10^{9} \mathrm{CFU} / \mathrm{g}\right)$, Lactobacillus acidophilus $\left(2 \times 10^{9} \mathrm{CFU} / \mathrm{g}\right)$ and L. casei $\left(2 \times 10^{9} \mathrm{CFU} / \mathrm{g}\right)$, for 6 weeks showed improved insulin sensitivity as assessed by the homoeostasis model assessment for insulin resistance (HOMA-IR) and quantitative insulin sensitivity check index (QUICKI), compared with a placebo capsule (cellulose). This probiotic supplementation also lowered TAG and VLDL levels, but this study did not measure $\mathrm{HbAlc}^{(48)}$. Moreover, oral supplementation of L. acidophilus NCFM (progenitor of the strain being used for complete chromosome sequencing in order to identify the relationship between genetics and probiotic functionality ${ }^{(60)}$ ) for 4 weeks improved insulin sensitivity as assessed by hyperinsulinaemic-euglycaemic clamp, compared with a placebo group, without changes in inflammatory markers such as TNF- $\alpha$, IL-6, IL-Ira and high-sensitivity C-reactive protein ${ }^{(43)}$

On the other hand, one study of overweight adults ${ }^{(59)}$ has shown conflicting results in that the intake of probiotic yogurt increased HOMA-IR $(P=0.038)$ and probiotic capsules significantly increased fasting glucose $(P=0.037)$ with no change in HOMA-IR ${ }^{(59)}$ ( $n 77$ for the probiotic group and $n 79$ for the probiotic capsule; the specific study design is shown in Table 1). The probiotics used were Lactobacillus acidophilus La5 and Bifidobacterium animalis subsp. lactis Bb12 (dose of $\left.3.0 \times 10^{9} \mathrm{CFU} / \mathrm{d}\right)^{(59)}$.

A single-blinded clinical trial of thirty-four subjects with T2DM showed no effects on glycaemic control, lipid profiles and inflammatory markers between a placebo group ( $n$ 18; $1000 \mathrm{mg}$ magnesium stearate) and a treatment group ( $n$ 16) who received $1500 \mathrm{mg}$ probiotic capsules containing Lactobacillus acidophilus, L. bulgaricus, L. bifidum and L. casei twice daily for 6 weeks ${ }^{(54)}$. However, this study provided no counts of probiotics used.

In summary, given the mixed results from human interventions, it is still unclear if probiotics favourably influence glucose control. More human interventions are needed with more comprehensive and dynamic measures of insulin sensitivity, as most studies did not use these. It is also required to investigate the treatment effects of specific strain(s) at different dosages and durations on insulin resistance.

\section{Other fermented food}

Kimchi, made with napa cabbage and various ingredients (garlic, red pepper powder, onion, ginger, radish, fermented fish sauce and starch syrup), is a fermented traditional Korean food. Kimchi can give health benefits due to its high nutritional value and abundant bioactive compounds including dietary fibres, minerals, amino acids, vitamins, carotenoids, glucosinolates and polyphenols. Kimchi can be improved by additional ingredients and altered fermentation conditions ${ }^{(61)}$. Fermented kimchi mostly contains lactic acid-producing bacteria including Lactobacillus plantarum, Lactobacillus brevis,
Pediococcus cerevisiae, Streptococcus faecalis and Leuconostoc mesenteroides, which could exert a probiotic effect ${ }^{(61)}$.

Studies have shown beneficial effects of fermented kimchi on glucose metabolism in obese ${ }^{(62)}$ and prediabetic individuals ${ }^{(63)}$.

Fermented kimchi intake for 4 weeks decreased fasting glucose, fasting insulin, total cholesterol, MCP-1, leptin and the waist:hip ratio compared with fresh kimchi in a cross-over design of twenty-two overweight and obese patients. Fresh kimchi was defined as 1 d-old kimchi and fermented kimchi was defined as $10 \mathrm{~d}$-old kimchi. The number of Lactobacilli in fermented kimchi was higher than in fresh kimchi $\left(4.3 \times 10^{9}\right.$ $\left.\left(\mathrm{sD} 1.2 \times 10^{9}\right) / \mathrm{ml} \quad v \cdot 1.4 \times 10^{7}\left(\mathrm{sD} 3 \times 10^{6}\right) / \mathrm{ml}\right)^{(62)}$. The consumption of fermented kimchi for 8 weeks decreased HbA1c, fasting insulin, HOMA and increased quantitative insulin sensitivity check index (QUICKI) and $\beta$-cell function compared with before fermented kimchi intake, in twenty-two adults with prediabetes $^{(63)}$.

A randomised controlled clinical trial in twenty-four obese women showed that fermented kimchi intake $(180 \mathrm{~g} / \mathrm{d})$ for 8 weeks altered gut microbiota composition, with a decrease in genus Blautia and an increase in Prevotella and Bacteroides, compared with fresh kimchi intake and up-regulated expression of genes related to the metabolic syndrome such as acyl-CoA synthetase long-chain family member 1 (ACSL1; involved in enhancing fatty acid degradation) and aminopeptidase $\mathrm{N}$ (ANPEP; involved in the regulation of pain, angiogenesis, inflammation and apoptosis) $)^{(64)}$.

Very recently, Shin et $a l .{ }^{(65)}$ demonstrated metabolic pathways of kimchi action based on in silico modelling of published data. A total of 4351 genes were associated with kimchi metabolites. Of these, 283 genes were associated with carbohydrate metabolism. In all, 309 genes were associated with lipid metabolism and twenty-seven genes (especially GNAS, CTNNB1, EDN1, RAC1 and adenyl cyclases ( $A D C Y 1, A D C Y 2, A D C Y 5)$ known to act as regulators of metabolic and cardiovascular function) are directly related with CVD. Twenty-three genes (especially PTPRC, LCK, $J A K 3, Z A P 7 O$ and VEGFA) were related to immune diseases and twenty-five genes were related to endocrine and metabolic diseases ${ }^{(65)}$. In summary, these inconsistent findings with probiotic interventions might result from heterogeneity in probiotic strains and populations. Intervention studies should be designed with a specific group and a specific strain ${ }^{(66)}$.

\section{Potential mechanisms of action of probiotics}

One potential mechanism of anti-diabetic effects is that certain probiotics facilitate production of SCFA (acetate $\left(\mathrm{C}_{2}\right)$, propionate $\left(\mathrm{C}_{3}\right)$ and butyrate $\left(\mathrm{C}_{4}\right)$ ), leading to the secretion of incretin hormones which may influence glucose levels ${ }^{(9,67)}$. Yadav et $a l .{ }^{(9)}$ have demonstrated a potential mechanism of probiotics through butyrate-induced secretion of glucagon-like peptide 1 (GLP-1) in mouse models. In this study ${ }^{(9)}$, VSL\#3 consisting of Lactobacillus casei, L. plantarum, L. acidophilus and L. delbrueckii subsp. bulgaricus, Bifidobacterium longum, $B$. breve and $B$. infantis and Streptococcus salivarius subsp. thermophilus was used. The levels of the SCFA butyrate in the mouse faecal samples significantly increased after VSL\#3 (daily oral dose of $5 \mathrm{mg} / \mathrm{kg}$ body weight), as measured by liquid 
chromatography-electrospray ionisation-tandem MS. Significantly increased plasma butyrate levels were observed in VSL\#3-treated mice compared with PBS-treated control mice. For the measurement of butyrate-producing bacteria, gene expression of butyrate kinase was assayed after 2 and 4 weeks of oral administration. Gene expression of butyrate kinase increased at 2 weeks in VSL\#3-treated mice. An increase in GLP-1 was observed in the human intestinal L-cell line NCI-H716 treated with butyrate ${ }^{(9)}$. GLP-1, an incretin hormone secreted by L-cells mainly in the ileum and large intestine, increases insulin secretion while glucagon is suppressed. GLP1 secretion results in delayed gastric emptying and reduced appetite, food intake and body-weight gain $^{(68)}$. Lactic acid produced by lactic acid-producing bacteria can be converted to acetate or propionate by Clostridium propionicum, Propionibacterium ssp., Desulfovibrio ssp, Veillonella ssp. and Selenomonas ssp. ${ }^{(69)}$ via methylmalonylCoA or acrylyl-CoA, and then to butyrate via acetyl-CoA by Eubacterium hallii (butyrate-producing species) ${ }^{(67)}$.

Other potential mechanisms of anti-diabetic effects of probiotics could be associated with enhanced immunity and increased anti-inflammatory cytokine production, reduced intestinal permeability and reduced oxidative stress ${ }^{(10,11,70,71)}$. In a randomised, double-blind, controlled intervention, patients with T2DM consumed $300 \mathrm{~g} / \mathrm{d}$ of yogurt (L. acidophilus La5, B. lactis Bb12 with a dose of $3.98 \times 10^{9} \mathrm{CFU}$ ) for 6 weeks and experienced a reduction in fasting glucose and $\mathrm{HbA} 1 \mathrm{c}$ and an increase in GPx and erythrocyte SOD activities and total antioxidant status, compared with the control $(300 \mathrm{~g} / \mathrm{d}$ of conventional yogurt). GPX and SOD are scavengers of reactive oxygen species $^{(10)}$.

Pre-incubation of HeLa cells with live Lactobacillus reuteri cells for $1-2 \mathrm{~h}$ inhibited translocation of NF- $\mathrm{kB}$ to the nucleus, inhibited degradation of IKKB (inhibitor of NF- $\mathrm{BB}$ kinase subunit $\beta$ ) and prevented expression of pro-inflammatory cytokines under NF- $\mathrm{BB}$ regulation. Live $L$. reuteri up-regulated nerve growth factor and inhibited constitutive synthesis and secretion of IL- 8 induced by TNF- $\alpha$ in T84 and HT29 cells (human colonic adenocarcinoma) ${ }^{(70)}$. Nerve growth factor is known to play roles in the regulation of inflammation ${ }^{(72,73)}$ and proliferation of pancreatic $\beta$-cells ${ }^{(74)}$. Metabolites of Lactobacillus plantarum 2142 down-regulated peroxide-induced elevation in proinflammatory cytokines IL- 8 and TNF- $\alpha$ in the IPEC-J2 cell line (jejunal epithelia isolated from neonatal piglet) ${ }^{(71)}$. In streptozotocin-induced diabetic rats, probiotic dahi containing Lactobacillus casei and Lactobacillus acidophilus suppressed streptozotocin-induced oxidative stress in pancreatic tissues by preventing the depletion of glutathione, GPx and SOD, as well as by decreasing thiobarbituric acid-reactive substances and nitrite $^{(11)}$. This finding implicates that probiotic dahi could delay streptozotocin-induced alteration in glucose homeostasis by exerting an antioxidant effect on $\beta$-cells ${ }^{(11)}$.

Prebiotics and effects of prebiotics on glucose metabolism in human interventions

Prebiotics are non-digestible food ingredients that are not metabolised or absorbed while passing through the upper gastrointestinal tract and are fermented by bacteria in the colon and selectively enhance the growth and/or activity of one or more potential beneficial bacteria (for example, Bifidobacterium and Lactobacillus) in the digestive system ${ }^{(75-77)}$.

Food sources of prebiotics are seeds, whole grains, legumes, chicory roots, Jerusalem artichokes, onions, garlic and some vegetables. Some prebiotics can be produced during the process of enzymic action or alcohol or cooking ${ }^{(77)}$.

Prebiotics include fructo-oligosaccharides (FOS), galactooligosaccharides, lactulose and large polysaccharides (inulin, resistant starches, cellulose, hemicellulose, pectin and gum) ${ }^{(75)}$. Of these, researchers have given more attention to $\mathrm{FOS}^{(77)}$. Synthetic oligosaccharides such as galacto-oligosaccharies have shown better effects and fewer side effects than natural forms ${ }^{(77)}$. Oligofructose-enriched inulin can act across the whole colon. Oligofructose is a short-chain fructan (a polymer of fructose molecules) containing three to ten monosaccharides linked together. It is quickly fermented and completely metabolised in the ascending part of the colon, whereas inulin is a long-chain fructan containing nine to sixty-four monosaccharides linked together. It is fermented and metabolised in the descending colon ${ }^{(77,78)}$.

Inulin-type fructans of $10-20 \mathrm{~g} / \mathrm{d}$ can normalise glucose tolerance or lipid profiles ${ }^{(79-84)}$. FOS or inulin of $4 \mathrm{~g} / \mathrm{d}$ is the minimal requirement for the enhancement of bifidobacteria growth but $14 \mathrm{~g} / \mathrm{d}$ or more of inulin can cause intestinal discomfort ${ }^{(77)}$.

In various animal studies, prebiotics have shown improved glucose metabolism ${ }^{(85,86)}$. However, a few human studies have demonstrated inconsistent findings. Human interventions of prebiotics are shown in Table 2.

\section{Fructo-oligosaccharides}

Seven studies have shown a favourable effect of FOS ${ }^{(87-93)}$ on glycaemic control, while three studies of $\operatorname{FOS}^{(94-96)}$ have shown no effect.

Forty-eight overweight or obese adults $\left(\mathrm{BMI}>25 \mathrm{~kg} / \mathrm{m}^{2}\right)$ in a randomised, double-blind, placebo-controlled trial received $21 \mathrm{~g}$ oligofructose per $\mathrm{d}$ or a placebo (maltodextrin) for 12 weeks. FOS supplementation decreased ghrelin, glucose and insulin, and increased peptide YY (PYY) compared with a placebo ${ }^{(90)}$. Yamashita et al. ${ }^{(87)}$ have also demonstrated a beneficial effect of supplementation of $8 \mathrm{~g}$ FOS per $\mathrm{d}$ for $14 \mathrm{~d}$ on glucose metabolism in individuals with T2DM. They found reductions in fasting glucose, total cholesterol and LDLcholesterol. The intake of short-chain FOS of $10.6 \mathrm{~g} / \mathrm{d}$ for 2 months reduced postprandial insulin response with no significant alteration in postprandial responses of glucose, NEFA and TAG in mild hypercholesterolaemic adults, compared with placebo $^{(88)}$. In a double-blind cross-over design, a daily consumption of $20 \mathrm{~g}$ FOS for 4 weeks decreased basal hepatic glucose production with no change in insulin-suppressed hepatic glucose production or insulin-stimulated glucose uptake using a hyperinsulinaemic clamp, compared with a daily consumption of $20 \mathrm{~g}$ sucrose in twelve healthy subjects ${ }^{(89)}$. However, in subjects with T2DM, supplementation of $20 \mathrm{~g}$ FOS had no effect on basal hepatic glucose production, fasting glucose and insulin concentrations ${ }^{(95)}$, and on blood glucose and serum lipids ${ }^{(94)}$. 
Table 2. Summary of prebiotic human intervention studies

\begin{tabular}{|c|c|c|c|c|c|c|c|}
\hline Source & Type and dose & Subjects & Design & Period & Outcomes & No effects & Reference \\
\hline Inulin & $\begin{array}{l}50 \mathrm{~g} / \mathrm{d} \text { of rice-based ready-to-eat cereal containing } \\
(18 \%) \text { inulin } v .50 \mathrm{~g} / \mathrm{d} \text { of rice-based ready-to-eat } \\
\text { cereal placebo }\end{array}$ & $\begin{array}{l}12 \text { Healthy men with mean BMI } \\
25.7 \mathrm{~kg} / \mathrm{m}^{2}\end{array}$ & $\mathrm{CO}$ & 4 weeks & $\begin{array}{l}\downarrow \text { TC, } \downarrow \text { TAG, } \uparrow \text { breath } \mathrm{H}_{2}, \uparrow \text { faecal lactic acid, } \\
\quad \uparrow \text { bifidobacteria }\end{array}$ & $\begin{array}{l}\text { Glyceamic responses, } \\
\text { faecal and bile acid } \\
\text { output, faecal SCFA, } \\
\text { faecal pH }\end{array}$ & $\begin{array}{l}\text { Brighenti et al. } \\
(1999)^{(83)}\end{array}$ \\
\hline Inulin & $10 \mathrm{~g} / \mathrm{d}$ of inulin $v .10 \mathrm{~g} / \mathrm{d}$ of maltodextrin placebo & $\begin{array}{l}54 \text { Middle-aged subjects } \\
\text { Treatment }(n 27) \\
\text { Placebo }(n 27)\end{array}$ & $\mathrm{RD}, \mathrm{DB}, \mathrm{PC}, \mathrm{P}$ & 8 weeks & $\begin{array}{l}\downarrow \text { Insulin at week } 4 \text { within the inulin group } v \text {. } \\
\text { baseline } \\
\downarrow \text { TAG in the inulin group } v \text {. the placebo group } \\
\text { at week } 8\end{array}$ & Fasting glucose & $\begin{array}{l}\text { Jackson et al. } \\
(1999)^{(80)}\end{array}$ \\
\hline Inulin & $\begin{array}{l}\text { Diet supplemented with } 10 \mathrm{~g} / \mathrm{d} \text { of inulin } v .10 \mathrm{~g} / \mathrm{d} \text { of } \\
\text { maltodextrin placebo }\end{array}$ & $\begin{array}{l}\text { Eight healthy subjects aged } \\
23-31 \text { years with BMl } \\
19-25 \mathrm{~kg} / \mathrm{m}^{2}\end{array}$ & $\mathrm{RD}, \mathrm{DB}, \mathrm{CO}, \mathrm{PC}$ & 3 weeks & $\downarrow$ TAG, $\downarrow$ hepatic lipogenesis & $\begin{array}{l}\text { Glucose, insulin, glucagon, } \\
\text { NEFA, lipids }\end{array}$ & $\begin{array}{l}\text { Letexier et al. } \\
\quad(2003)^{(84)}\end{array}$ \\
\hline Inulin & $\begin{array}{l}\text { Diet supplemented } 11 \% \text { inulin-enriched pasta } \\
\quad(100 \mathrm{~g} / \mathrm{d}) \mathrm{v} \text {. wheat pasta }(100 \mathrm{~g} / \mathrm{d}) \text { placebo diet }\end{array}$ & 15 Healthy males & $\mathrm{RD}, \mathrm{DB}, \mathrm{CO}$ & 5 weeks & $\begin{array}{l}\downarrow \text { HbA1c, } \downarrow \text { HOMA-IR, } \downarrow \text { fasting glucose, } \\
\downarrow \downarrow \text { fructosamine, } \downarrow \text { gastric empting, } \\
\quad \downarrow \text { TC, } \uparrow \mathrm{HDL}, \downarrow \text { TAG }\end{array}$ & & $\begin{array}{l}\text { Russo et al. } \\
\quad(2010)^{(81)}\end{array}$ \\
\hline Inulin & $\begin{array}{l}\text { Low-energy diet plus one of following treatments: } \\
\text { (a) PMR alone; (b) PMR }+10 \mathrm{~g} / \mathrm{d} \text { of inulin; } \\
\text { (c) } 10 \mathrm{~g} / \mathrm{d} \text { of inulin alone; (d) control (no inulin or PMR) }\end{array}$ & $\begin{array}{l}110 \text { Obese women aged } 18-50 \\
\text { years with } \mathrm{BMI} \geq 25 \mathrm{~kg} / \mathrm{m}^{2} \\
\text { (a) }(n 28),(\text { b) }(n 23) \\
\text { (c) }(n 30),(\text { d) }(n 29)\end{array}$ & $\mathrm{RD}, \mathrm{C}, \mathrm{L}, \mathrm{P}$ & 12 weeks & $\downarrow$ TAG & Glucose, TC, HDL-C & $\begin{array}{l}\text { Tovar et al. } \\
(2012)^{(97)}\end{array}$ \\
\hline $\begin{array}{l}\text { Chicory } \\
\text { root } \\
\text { inulin }\end{array}$ & $\begin{array}{l}\text { Diet supplemented with } 1 \text { pint }(0.4732 \text { litres) of low-fat } \\
\text { vanilla ice cream made with } 20 \mathrm{~g} / \mathrm{d} \text { of inulin } v \text {. the } \\
\text { same diet supplemented with } 1 \text { pint of low-fat vanilla } \\
\text { ice cream made with sucrose }\end{array}$ & 12 Men with HC & $\mathrm{RD}, \mathrm{DB}, \mathrm{CO}$ & 3 weeks & $\downarrow$ TC, $\downarrow$ TAG & Glucose, insulin & $\begin{array}{l}\text { Causey et al. } \\
(2000)^{(98)}\end{array}$ \\
\hline $\begin{array}{r}\text { Chicory } \\
\text { inulin }\end{array}$ & $\begin{array}{l}\text { Diet supplemented with } 16 \mathrm{~g} / \mathrm{d} \text { of chicory-derived fructan/ } \\
\mathrm{d} v \text {. diet with } 16 \mathrm{~g} / \mathrm{d} \text { of maltodextrin placebo }\end{array}$ & $\begin{array}{l}10 \text { Healthy adults with mean } \\
\text { BMl } 21.6 \mathrm{~kg} / \mathrm{m}^{2} \\
\text { Treatment }(n 5) \\
\text { Placebo }(n 5)\end{array}$ & RD, DB, P, PC & 2 weeks & $\begin{array}{l}\downarrow \text { Postprandial glucose, } \uparrow \text { breath } \mathrm{H}_{2} \\
\quad \downarrow \text { hunger, } \uparrow \text { GLP- } 1, \uparrow \text { PYY }\end{array}$ & Fasting glucose, insulin & $\begin{array}{l}\text { Cani et al. } \\
\quad(2009)^{(82)}\end{array}$ \\
\hline $\begin{array}{l}\text { Inulin } \\
\text { and } \\
\text { FOS }\end{array}$ & $\begin{array}{l}\text { Yacon syrup with about } 12.5 \mathrm{~g} / \mathrm{d} \text { of FOS } v \text {. placebo } \\
\text { syrup containing } 2.5 \% \text { tartaric acid, } 1.8 \% \\
\text { carboxymethylcellulose, } 2.5 \% \text { saccharine and } \\
10 \% \text { glycerine }\end{array}$ & $\begin{array}{l}35 \text { Obese women with mean } \\
\text { BMI } 33.5 \mathrm{~kg} / \mathrm{m}^{2} \\
\text { Treatment }(n 20) \\
\text { Placebo }(n 15)\end{array}$ & $\mathrm{DB}, \mathrm{PC}, \mathrm{P}$ & 17 weeks & $\begin{array}{l}\downarrow \text { Fasting insulin, } \downarrow \text { HOMA-IR, } \downarrow \text { LDL-C, } \\
\quad \uparrow \text { satiety, } \downarrow \text { BMI, } \downarrow \text { waist circumference }\end{array}$ & $\begin{array}{l}\text { Fasting glucose, TC, } \\
\text { HDL-C, TAG }\end{array}$ & $\begin{array}{l}\text { Genta et al. } \\
(2009)^{(92)}\end{array}$ \\
\hline $\begin{array}{l}\text { Inulin } \\
\text { and } \\
\text { FOS }\end{array}$ & $\begin{array}{l}16 \mathrm{~g} / \mathrm{d} \text { mixture of inulin and FOS }(50 / 50) \text { v. placebo } \\
\text { maltodextrin. Dietary instruction given to all } \\
\text { participants for weight loss }\end{array}$ & $\begin{array}{l}30 \text { Obese women } \\
\text { Treatment }(n 15) \\
\text { Placebo }(n \text { 15) }\end{array}$ & $\mathrm{DB}, \mathrm{PC}, \mathrm{P}$ & 12 weeks & $\begin{array}{l}\downarrow \text { Post-OGTT glycaemia within the treated } \\
\text { group, } \downarrow \text { LPS } \\
\downarrow \text { Bacteroides intestinalis, Bacteroides vulgatus } \\
\text { and Propionibacterium } \\
\uparrow \text { Bifidobacterium and Faecalibacterium } \\
\text { prausnitzii } \\
\downarrow \text { Bacteroides intestinalis, Bacteroides vulgatus } \\
\text { and Propionibacterium }\end{array}$ & $\begin{array}{l}\text { HbA1c, fasting glycaemia, } \\
\text { insulinaemia, post-OGTT } \\
\text { insulinaemia, HOMA, } \\
\text { adiponectinaemia, } \\
\text { hs-CRP }\end{array}$ & $\begin{array}{l}\text { Dewulf et al. } \\
\qquad(2013)^{(99)}\end{array}$ \\
\hline $\begin{array}{l}\text { FOS- } \\
\text { enri- } \\
\text { ched } \\
\text { inulin }\end{array}$ & $\begin{array}{l}10 \mathrm{~g} / \mathrm{d} \text { of FOS-enriched inulin } v .10 \mathrm{~g} / \mathrm{d} \text { of maltodextrin } \\
\text { placebo }\end{array}$ & $\begin{array}{l}52 \text { Diabetic women with BMI } \\
>25 \text { but }<35 \mathrm{~kg} / \mathrm{m}^{2} \\
\text { Treatment }(n 27) \\
\text { Placebo }(n 25)\end{array}$ & $\mathrm{RD}, \mathrm{PC}, \mathrm{P}$ & 8 weeks & $\begin{array}{l}\downarrow \text { Fasting glucose, } \downarrow \text { glycosylated } \mathrm{Hb}, \\
\quad \downarrow \text { IL-6, } \downarrow \text { TNF-a, } \downarrow \text { LPS }\end{array}$ & hs-CRP, IL-10, interferon- $\gamma$ & $\begin{array}{l}\text { Dehghan et al. } \\
\qquad(2014)^{(78)}\end{array}$ \\
\hline FOS & $8 \mathrm{~g} / \mathrm{d}$ of FOS $v .5 \mathrm{~g} / \mathrm{d}$ of placebo sucrose & $\begin{array}{l}28 \text { Patients with T2DM } \\
\text { Treatment }(n 18) \\
\text { Placebo }(n 10)\end{array}$ & $\mathrm{RD}, \mathrm{PC}, \mathrm{P}$ & 2 weeks & $\downarrow$ Fasting glucose, $\downarrow$ TC, $\downarrow$ LDL-C & NEFA, TAG, HDL-C & $\begin{array}{l}\text { Yamashita } \\
\text { et al. } \\
(1984)^{(87)}\end{array}$ \\
\hline FOS & $20 \mathrm{~g} / \mathrm{d}$ FOS v. $20 \mathrm{~g} / \mathrm{d}$ sucrose & 12 Healthy subjects & $\mathrm{RD}, \mathrm{DB}, \mathrm{CO}$ & 4 weeks & $\downarrow$ Basal hepatic glucose production & $\begin{array}{l}\text { Fasting glucose, insulin, } \\
\text { lipids }\end{array}$ & $\begin{array}{l}\text { Luo et al. } \\
\qquad(1996)^{(89)}\end{array}$ \\
\hline FOS & $15 \mathrm{~g} / \mathrm{d}$ of FOS $v .4 \mathrm{~g} / \mathrm{d}$ of placebo glucose & 20 Patients with T2DM & $\mathrm{RD}, \mathrm{SB}, \mathrm{CO}$ & $20 \mathrm{~d}$ & & $\begin{array}{l}\text { Glucose, lipids, TAG, NEFA, } \\
\text { acetate }\end{array}$ & $\begin{array}{l}\text { Alles et al. } \\
\qquad(1999)^{(94)}\end{array}$ \\
\hline FOS & $20 \mathrm{~g} / \mathrm{d}$ of FOS $v .20 \mathrm{~g} / \mathrm{d}$ of placebo sucrose & 10 Patients with T2DM & $\begin{array}{l}\mathrm{DB}, \mathrm{CO} \text {, no } \\
\text { washout }\end{array}$ & 4 weeks & & $\begin{array}{l}\text { Basal hepatic glucose } \\
\text { production, fasting } \\
\text { glucose, insulin, lipids }\end{array}$ & $\begin{array}{l}\text { Luo et al. } \\
\qquad(2000)^{(95)}\end{array}$ \\
\hline sc-FOS & $\begin{array}{l}10.6 \mathrm{~g} / \mathrm{d} \text { of sc-FOS } \mathrm{v} .15 \mathrm{~g} / \mathrm{d} \text { of placebo maltodextrin and } \\
\text { aspartame with tea and/or coffee }\end{array}$ & 30 Adults with mild $\mathrm{HC}$ & $\mathrm{RD}, \mathrm{DB}, \mathrm{CO}$ & 8 weeks & $\downarrow$ Postprandial insulin response & $\begin{array}{l}\text { Postprandial effects on } \\
\text { glucose, NEFA, TAG }\end{array}$ & $\begin{array}{l}\text { Giacco et al. } \\
(2004)^{(88)}\end{array}$ \\
\hline FOS & $\begin{array}{l}\text { Diet supplemented with } 16 \mathrm{~g} / \mathrm{d} \text { of FOS } v \text {. diet with } \\
\text { placebo } 16 \mathrm{~g} / \mathrm{d} \text { of maltodextrin }\end{array}$ & $\begin{array}{l}\text { Seven male adults with non- } \\
\text { alcoholic steatohepatitis } \\
\left.\text { (mean BMl } 29 \cdot 1 \mathrm{~kg} / \mathrm{m}^{2}\right)\end{array}$ & $\mathrm{RD}, \mathrm{DB}, \mathrm{CO}$ & 8 weeks & $\begin{array}{l}\downarrow \text { Aminotransferases, } \downarrow \text { AST after } 8 \text { weeks, } \\
\downarrow \text { insulin at } 4 \text { weeks }\end{array}$ & Insulin after 8 weeks & $\begin{array}{l}\text { Daubioul et al. } \\
\quad(2005)^{(91)}\end{array}$ \\
\hline
\end{tabular}




\begin{tabular}{|c|c|c|c|c|c|c|c|}
\hline Source & Type and dose & Subjects & Design & Period & Outcomes & No effects & Reference \\
\hline FOS & $\begin{array}{l}\text { (a) FOS-rich yacon syrup (0.29g FOS/body weight } \\
\text { per d) } \\
\text { (b) FOS-rich yacon syrup ( } 0.14 \mathrm{~g} \mathrm{FOS/body} \mathrm{weight} \\
\text { per d) } \\
\text { (c) placebo }\end{array}$ & $\begin{array}{l}55 \text { Obese slightly } \\
\text { dyslipidaemic } \\
\text { premenopausal women } \\
\text { Treatment }(n 40) \\
\text { Placebo }(n 15)\end{array}$ & $\mathrm{DB}, \mathrm{PC}, \mathrm{P}$ & $120 \mathrm{~d}$ & $\begin{array}{l}\downarrow \text { Fasting insulin, HOMA-IR, BMI and LDL-C } \\
\text { within the yacon syrup at } 0.14 \mathrm{~g} \mathrm{FOS/body} \\
\text { weight per } d v \text {. baseline }\end{array}$ & $\begin{array}{l}\text { Fasting glucose, TC, } \\
\text { HDL-C, TAG }\end{array}$ & $\begin{array}{l}\text { Genta et al. } \\
(2009)^{(92)}\end{array}$ \\
\hline FOS & $21 \mathrm{~g} / \mathrm{d}$ of FOS $v \cdot 7.9 \mathrm{~g} / \mathrm{d}$ of placebo maltodextrin & $\begin{array}{l}39 \text { Overweight or obese adults } \\
\text { with BMI }>25 \mathrm{~kg} / \mathrm{m}^{2} \\
\text { Treatment }(n 21) \\
\text { Placebo }(n 18)\end{array}$ & $\mathrm{RD}, \mathrm{DB}, \mathrm{PC}, \mathrm{P}$ & 12 weeks & $\begin{array}{l}\downarrow \text { Ghrelin, } \uparrow \text { PYY, } \downarrow \text { postprandial insulin, } \downarrow \text { body } \\
\text { weight, } \downarrow \text { fat mass, } \downarrow \text { energy intake }\end{array}$ & $\begin{array}{l}\text { Postprandial glucose, } \\
\text { GLP-1, GIP, leptin, lipids }\end{array}$ & $\begin{array}{l}\text { Parnell \& } \\
\text { Reimer } \\
(2009)^{(90)}\end{array}$ \\
\hline FOS & $30 \mathrm{~g} / \mathrm{d}$ of FOS $v .30 \mathrm{~g} / \mathrm{d}$ of placebo cellulose & $\begin{array}{l}22 \text { Healthy obese subjects with } \\
\text { BMl } 25-35 \mathrm{~kg} / \mathrm{m}^{2} \text { aged } \\
20-50 \text { years } \\
\text { Treatment }(n 12) \\
\text { Placebo }(n 10)\end{array}$ & $\mathrm{P}, \mathrm{SB}, \mathrm{PC}$ & 6 weeks & $\uparrow \mathrm{PYY}, \downarrow$ appetite & $\begin{array}{l}\text { AST, ALT, GGT, glucose, } \\
\text { insulin, HOMA-IR, } \\
\text { HOMA \% B, lipids, } \\
\text { GLP-1 }\end{array}$ & $\begin{array}{l}\text { Daud et al. } \\
\qquad(2014)^{(96)}\end{array}$ \\
\hline FOS & $\begin{array}{l}18 \mathrm{~g} / \mathrm{d} \text { of freeze-dried powdered yacon containing } 7.4 \mathrm{~g} / \mathrm{d} \\
\text { of FOS } v \text {. placebo ( } 18 \mathrm{~g} / \mathrm{d} \text { of maltodextrin) }\end{array}$ & $\begin{array}{l}72 \text { Elderly subjects aged } \\
>60 \text { years } \\
\text { Treatment }(n 37) \\
\text { Placebo }(n 35)\end{array}$ & $\mathrm{RD}, \mathrm{DB}, \mathrm{PC}, \mathrm{P}$ & 9 weeks & $\begin{array}{l}\downarrow \text { Serum glucose within the treatment group } v \text {. } \\
\text { baseline }\end{array}$ & $\begin{array}{l}\text { Insulin, HOMA-IR, lipids, } \\
\text { hs-CRP }\end{array}$ & $\begin{array}{l}\text { Scheid et al. } \\
\quad(2014)^{(93)}\end{array}$ \\
\hline RS & $\begin{array}{l}60 \mathrm{~g} / \mathrm{d} \text { of RS (Novelose } 260) v . \text { placebo } \\
\text { (0 g/d of RS) }\end{array}$ & 10 Healthy adults & $\mathrm{SB}, \mathrm{CO}, \mathrm{PC}, \mathrm{P}$ & $24 \mathrm{~h}$ & $\begin{array}{l}\downarrow \text { Postprandial glucose and insulin, } \\
\uparrow \text { insulin sensitivity by a minimal } \\
\text { model approach }\end{array}$ & TAG & $\begin{array}{l}\text { Robertson } \\
\text { et al. } \\
\quad(2003)^{(102)}\end{array}$ \\
\hline RS & $30 \mathrm{~g} / \mathrm{d}$ of $\mathrm{RS} v$. placebo $(0 \mathrm{~g} / \mathrm{d}$ of RS) & $\begin{array}{l}10 \text { Healthy adults with mean } \\
\text { BMI } 23.4 \mathrm{~kg} / \mathrm{m}^{2}\end{array}$ & $\mathrm{SB}, \mathrm{CO}, \mathrm{PC}, \mathrm{P}$ & 4 weeks & $\begin{array}{l}\uparrow \text { Insulin sensitivity by hyperinsulinaemic- } \\
\text { euglycaemic clamp at } 3 \text { weeks, } \downarrow \text { insulin } \\
\text { AUC at } 4 \text { weeks, } \uparrow \text { insulin sensitivity by MTT } \\
\text { at } 4 \text { weeks }\end{array}$ & $\begin{array}{l}\text { Fasting glucose and insulin } \\
\text { by MTT at } 4 \text { weeks }\end{array}$ & $\begin{array}{l}\text { Robertson } \\
\text { et al. } \\
\quad(2005)^{(100)}\end{array}$ \\
\hline RS & $\begin{array}{c}\text { Low } \beta \text {-glucan (low, medium and high RS) } v \text {. medium } \\
\beta \text {-glucan (low, medium and high RS) v. high } \\
\beta \text {-glucan (low, medium and high RS) } v \text {. glucose }\end{array}$ & $\begin{array}{l}10 \text { Normal-weight and } 10 \\
\text { overweight women }\end{array}$ & MTT & & $\downarrow$ Glucose and insulin AUC & & $\begin{array}{l}\text { Behall et al. } \\
(2006)^{(106)}\end{array}$ \\
\hline RS & $40 \mathrm{~g} / \mathrm{d}$ of RS $v$. placebo $(0 \mathrm{~g} / \mathrm{d}$ of RS) & 20 Insulin-resistant subjects & $\mathrm{SB}, \mathrm{RD}, \mathrm{PC}, \mathrm{P}$ & 12 weeks & $\begin{array}{l}\uparrow \text { Insulin sensitivity by euglycaemic- } \\
\text { hyperinsulinaemic clamp }\end{array}$ & $\begin{array}{l}\text { Adiposity, lipids, } \\
\text { inflammatory markers }\end{array}$ & $\begin{array}{l}\text { Johnston et al. } \\
\quad(2010)^{(103)}\end{array}$ \\
\hline RS & $\begin{array}{l}15 \mathrm{~g} / \mathrm{d} \text { of HAM-RS2 v. } 30 \mathrm{~g} / \mathrm{d} \text { HAM-RS2 } 1 \mathrm{v} \text {. control } \\
(0 \mathrm{~g} / \mathrm{d} \text { of HAM-RS2) }\end{array}$ & $\begin{array}{l}\text { Overweight and obese adults } \\
(11 \text { men and } 22 \text { women) }\end{array}$ & $\mathrm{RD}, \mathrm{DB}, \mathrm{CO}, \mathrm{C}$ & 4 weeks & $\begin{array}{l}\uparrow \text { Insulin sensitivity in men by insulin-modified } \\
\text { intravenous glucose tolerance test }\end{array}$ & $\begin{array}{l}\text { Fasting glucose, insulin, } \\
\text { HOMA-IR, hs-CRP, } \\
\text { fructosamine adiponectin }\end{array}$ & $\begin{array}{l}\text { Maki et al. } \\
\quad(2012)^{(104)}\end{array}$ \\
\hline RS & $24 \mathrm{~g} / \mathrm{d}$ of RS $v$. control $(0 \mathrm{~g} / \mathrm{d}$ of RS) & $\begin{array}{l}86 \text { subjects both with the MetS } \\
\text { and without the MetS }\end{array}$ & $\mathrm{DB}, \mathrm{CO}, \mathrm{PC}, \mathrm{P}$ & 12 weeks & $\begin{array}{l}\downarrow \text { Cholesterol in subjects with the MetS, } \\
\downarrow \text { body fat composition }\end{array}$ & $\begin{array}{l}\text { Fasting glucose, } \\
\text { postprandial glucose, } \\
\text { HbA1c }\end{array}$ & $\begin{array}{l}\text { Nichenametla } \\
\text { et al. } \\
(2014)^{(107)}\end{array}$ \\
\hline RS & $\begin{array}{l}40 \mathrm{~g} / \mathrm{d} \text { of type } 2 \text { RS (HAM-RS2) v. placebo } \\
(0 \mathrm{~g} / \mathrm{d} \text { of RS) }\end{array}$ & $\begin{array}{l}17 \text { Diabetic adults with mean } \\
\text { BMl } 30.6 \mathrm{~kg} / \mathrm{m}^{2} \text { aged mean } \\
55 \text { years }\end{array}$ & $\mathrm{SB}, \mathrm{RD}, \mathrm{CO}$ & 12 weeks & $\begin{array}{c}\downarrow \text { Postprandial glucose by MTT, } \\
\downarrow \text { TAG, } \uparrow \text { GLP- } 1, \downarrow \text { TNF } a\end{array}$ & $\begin{array}{l}\text { Fasting glucose, insulin, } \\
\text { HOMA-IR, insulin } \\
\text { sensitivity, HbA1c, } \\
\text { C-peptide, lipids, IL-6 }\end{array}$ & $\begin{array}{l}\text { Bodinham } \\
\text { et al. } \\
(2014)^{(105)}\end{array}$ \\
\hline RS & $\begin{array}{l}\text { Barley kernel-based bread high in RS and NSP }(37.6 \mathrm{~g} / \mathrm{d} \\
\text { of total dietary fibre) } v \text {. white wheat bread }(9.1 \mathrm{~g} / \mathrm{d} \text { of } \\
\text { total dietary fibre) }\end{array}$ & $\begin{array}{l}20 \text { Healthy middle-aged } \\
\text { subjects }\end{array}$ & $\mathrm{RD}, \mathrm{CO}$ & $3 d$ & $\begin{array}{l}\uparrow \text { Fasting GLP-1, } \uparrow \text { postprandial PYY and } \\
\text { GLP-2, } \uparrow \text { breath } \mathrm{H}_{2}, \uparrow \text { fasting SCFA, } \uparrow \text { insulin } \\
\text { sensitivity, } \downarrow \text { blood glucose and serum } \\
\text { insulin responses to the standardised } \\
\text { breakfast }\end{array}$ & $\begin{array}{l}\text { Fasting glucose, insulin, } \\
\text { HOMA-IR, inflammatory } \\
\text { markers }\end{array}$ & $\begin{array}{l}\text { Nilsson et al. } \\
\quad(2015)^{(101)}\end{array}$ \\
\hline
\end{tabular}

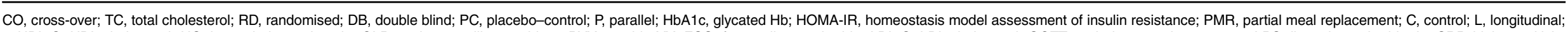

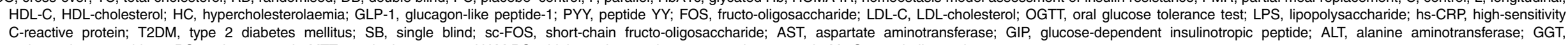

Y-glutamyltranspeptidase; RS, resistant starch; MTT, meal tolerance test: HAM-RS2, high-amylose maize type 2 resistant starch; MetS, metabolic syndrome. 
Inulin

Effects of inulin on glycaemic control have shown mixed results, with three interventions ${ }^{(80-82)}$ showing a positive effect and four interventions ${ }^{(83,84,97,98)}$ showing no effect.

In a parallel study of fifty-four subjects receiving $10 \mathrm{~g}$ inulin ( $n$ 27) or maltodextrin ( $n$ 27) daily for 8 weeks, insulin concentrations were lower at 4 weeks within the inulin group compared with baseline, but no differences were observed at weeks 4 and 8 in comparison with a placebo. No effect of inulin on fasting glucose concentrations was observed compared with a placebo ${ }^{(80)}$. However, in a cross-over study of twelve men with hypercholesterolaemia, a diet supplemented with 1 pint ( 0.4732 litres) of vanilla ice cream made with $20 \mathrm{~g}$ inulin for 3 weeks decreased total cholesterol and TAG but did not alter glucose and insulin, compared with the same diet supplemented with 1 pint of vanilla ice cream made with sucrose ${ }^{(98)}$.

\section{Oligofructose-enriched inulin}

Three interventions have shown favourable effects on glycaemic control when a combination of FOS and inulin was used $^{(78,92,99)}$. In a randomised controlled study of fifty-two women with T2DM, $10 \mathrm{~g}$ FOS-enriched inulin per d $(n$ 27) for 8 weeks lowered fasting glucose and glycosylated $\mathrm{Hb}$ and improved inflammatory markers (IL-6, TNF- $\alpha$ ) and decreased LPS, compared with a placebo (maltodextrin; $n 25)^{(78)}$. Further research is necessary to clarify the effects of oligofructoseenriched inulin on glucose metabolism.

\section{Resistant starch}

Consumption of resistant starch improved insulin sensitivity in healthy subjects ${ }^{(100-102)}$ or in subjects with the metabolic syndrome $^{(103,104)}$, and lowered postprandial glucose or insulin in individuals with T2DM ${ }^{(105)}$ and women ${ }^{(106)}$. One study ${ }^{(107)}$ showed no difference in glycaemic control. The $3 \mathrm{~d}$ intake of barley kernelbased bread rich in resistant starch and NSP increased fasting SCFA levels, gut hormones (fasting GLP-1, postprandial PYY and GLP-2) secretion and breath $\mathrm{H}_{2}$ excretion, and improved insulin sensitivity (the Matsuda index) after consuming a standardised breakfast, compared with white wheat bread ${ }^{(101)}$

In summary, the effects of prebiotics (inulin or FOS or oligofructose-enriched inulin administration) on glucose and lipid metabolism are not clear, but resistant starch appears to have a favourable effect on insulin sensitivity.

\section{Other potential prebiotics}

Costabile et al. ${ }^{(108)}$ suggested that whole-grain wheat could exert a prebiotic effect on gut microbiota composition. This double-blind, randomised, cross-over trial comparing $100 \%$ whole-grain breakfast cereal of $48 \mathrm{~g} / \mathrm{d}$ with wheat bran breakfast cereal of $48 \mathrm{~g} / \mathrm{d}$ for 3 weeks showed that whole grain significantly increased the number of faecal bifidobacteria and lactobacilli compared with the wheat bran cereal. However, there were no significant differences in faecal SCFA, fasting glucose, insulin, total cholesterol, TAG or HDL-cholesterol for whole grain intake compared with whole bran ${ }^{(108)}$.
Potential mechanisms of action of prebiotic-derived SCFA in insulin sensitivity

Microbial fermentation of prebiotics facilitates the production of SCFA (essential endproducts of carbohydrate metabolism) and enhances gut barrier function ${ }^{(109)}$. In a mouse model, a prebiotic treatment decreased intestinal permeability and increased GLP-2 secretion, and reducing the hepatic expression of inflammatory and oxidative stress markers and decreasing LPS during obesity and diabetes ${ }^{(109)}$.

\section{SCFA and free fatty acid receptors}

SCFA in the intestine activate G-protein-coupled receptors (GPR), such as GPR41 (namely, free fatty acid receptor 3; FFAR3) and GPR43 (namely, free fatty acid receptor 2; FFAR2). These receptors are present on ileal and colonic enteroendocrine L-cells, adipocytes and immune cells ${ }^{(110)}$. Both GPR41 and GPR43 on intestinal epithelia L-cells trigger the secretion of gut hormones (GLP-1 and PYY). Leptin is also released from adipocytes when SCFA bind to GPR41. PYY, GLP1 and leptin can decrease appetite ${ }^{(111-114)}$. GLP-1 increases insulin secretion from pancreatic $\beta$-cells and decreases glucagon secretion from the pancreatic islets, which leads to lower glucose output from the liver and enhanced peripheral uptake of glucose. GLP1 may suppress appetite and food intake via the autonomic nervous system or the brain $^{(75,115,116)}$. It is known that FFAR3 is activated by butyrate and propionate while FFAR2 is activated by acetate and propionate ${ }^{(117)}$. FFAR3 knockout mice showed that butyrate and propionate inhibited food intake, reduced high-fat diet-induced weight gain and glucose intolerance and enhanced gut hormone release. FFAR3 was necessary for the maximal induction of GLP-1 by butyrate, whereas FFAR3 was unnecessary for the effects on body weight and glucose-dependent insulinotropic peptide secretion $^{(118)}$. FFAR3 and FFAR2 can be expressed in several cells such as adipocytes, endocrine cells (for example, pancreatic islets) and immune cells ${ }^{(119)}$. FFAR2 is highly expressed in immune cells (neutrophils and monocytes) and haematopoietic tissues, compared with FFAR3 ${ }^{(120)}$. SCFA can exert potent roles in inhibiting lipolysis and inflammation, and regulating energy metabolism ${ }^{(119,120-122)}$. Ge et al. $^{(121)}$ demonstrated that when FFAR2 on adipocytes was activated by SCFA (acetate and propionate), adipocyte lipolysis and differentiation were inhibited, while in GPR43 knockout animals, this was not observed, suggesting that prebiotic fermentation could be detrimental with regard to obesity ${ }^{(121)}$. However, obese mice and human studies of prebiotics (especially, inulin-type fructans) have not shown this ${ }^{(123,124)}$. SCFA inhibited the production of MCP-1 and LPSinduced IL-10 in human monocytes, as well as LPS-induced TNF- $\alpha$ and interferon- $\gamma$ in human peripheral blood mononuclear cells (PBMC: monocytes and lymphocytes (T-cells, B-cells and natural killer cells) $)^{(120)}$.

\section{Anti-inflammatory effects}

Elevated pro inflammatory makers such as high-sensitivity C-reactive protein, TNF- $\alpha$ and IL- 6 are increased in T2DM ${ }^{(78)}$. SCFA can suppress these inflammatory mediators ${ }^{(120,125-128)}$. 
SCFA (acetate, propionate, and butyrate) decrease $\mathrm{NO}^{(125)}$. NO is produced by NO synthase which converts oxygen and arginine to citrulline and NO. NO acts as a vasodilator with beneficial effects on vascular health ${ }^{(129-132)}$ and has an anti-inflammatory effect under normal physiological conditions ${ }^{(133)}$. However, NO participates in immune responses by cytokine-activated macrophages which produce NO in high concentrations ${ }^{(133)}$.

SCFA suppressed LPS-stimulated TNF- $\alpha^{(126)}$ from neutrophils and also suppressed TNF- $\alpha$, IL-1 $\beta$, IL- 6 and NO in RAW $264 \cdot 7$ murine macrophage cells ${ }^{(127)}$. Moreover, SCFA $(0 \cdot 2-20 \mathrm{mmol} / \mathrm{l})$ lowered the LPS-induced production of TNF- $\alpha$ and interferon- $\gamma$ in human PBMC in a dose-dependent manner ${ }^{(120)}$. Butyrate suppressed IL- 6 and TNF- $\alpha$ in interferon- $\boldsymbol{\gamma}$-stimulated RAW 264.7 murine macrophage cells ${ }^{(128)}$. Studies ${ }^{(125,126,128)}$ showed that anti-inflammatory effects of SCFA could be mediated by inhibiting the activation of $\mathrm{NF}-\mathrm{\kappa B}$ (a transcriptional factor involved in the inflammatory response and cell proliferation and TNF- $\alpha$ production $\left.{ }^{(134)}\right)$. Butyrate is a histone deacetylase inhibitor $^{(134,135)}$. SCFA (propionate and butyrate) suppressed the release of LPS-stimulated TNF- $\alpha$ and down-regulated NF- $\kappa \mathrm{B}$ by facilitating $\mathrm{PGE}_{2}$ levels and cyclo-oxygenase- 2 activities through inhibiting histone deacetylase in $\mathrm{PBMC}^{(134)}$ and murine macrophage cell line RAW 264.7 cells $^{(135)}$. Therefore, SCFA, especially butyrate, exert an anti-inflammatory effect via two potential signalling pathways of NF- $\mathrm{KB}$ and histone deacetylase inhibition.

Butyrate also decreased the levels of MCP-1 in a dosedependent manner with or without LPS in human PBMC ${ }^{(120)}$. SCFA inhibited the expression of vascular cell adhesion molecule- 1 induced by TNF- $\alpha$ and IL- $1 \beta$ in human umbilical vein endothelial cells ${ }^{(136-138)}$. Butyrate suppressed T-cell activation stimulated by antigen-presenting cells by down-regulating the expression of intracellular cell adhesion molecule-1 and lymphocyte function-associated antigen-3 in monocytes ${ }^{(139)}$.

\section{SCFA and angiopoietin-like protein 4}

Angiopoietin-like protein 4 (ANGPTL4) is a $50 \mathrm{kDa}$ prohormone secreted from brown and white adipose tissues, liver, skeletal muscle, intestine and heart. Human ANGPTL4 is mainly expressed in the liver. It is known as fasting-induced adipose factor because ANGPTL4 is up-regulated in white adipose tissue and liver during fasting ${ }^{(110,140)}$, while human plasma ANGPTL4 concentrations are reduced after meal consumption $^{(140)}$. ANGPTL4 is a lipoprotein lipase inhibitor and thus causes decreased uptake of fatty acids into tissue ${ }^{(110)}$. In mice, overexpression of ANGPTL4 decreased clearance of TAGrich lipoproteins and increased circulating TAG levels ${ }^{(141)}$. A very recent study showed that inhibition of or a lower level of ANGPTL 4 is associated with lower risk of CVD in mice and nonhuman primate models ${ }^{(142)}$. The suppressed ANGPTL4 may result in increased lipoprotein lipase activity and lipolysis ${ }^{(75,115)}$.

On the other hand, lower serum ANGPTL4 levels are observed in subjects with T2DM compared with normal subjects. An inverse association between plasma glucose levels and HOMA-IR, and serum ANGPTL4 levels was found. These findings suggest that decreased ANGPTL4 could play a role in glucose tolerance ${ }^{(143)}$.
ANGPTL4 induced by fatty acids via PPAR in various tissues appears to reduce cellular lipid overload, oxidative stress and inflammation ${ }^{(144,145)}$. The SCFA, especially propionate, inhibited lipid synthesis in the presence of acetate as a source of acetyl-CoA in hepatocytes ${ }^{(146)}$. Propionate and/or butyrate, but not acetate, activated ANGPTL4 production in intestinal (Caco-2, HT-29 and HCT-116) and hepatic (HepG2) cancer cell lines ${ }^{(147)}$ and the entero-endocrine cell line HuTu-80 from the human small intestine $^{(140)}$.

ANGPTL4 is a downstream target gene of PPAR ${ }^{(75)}$. PPAR, transcription factors with three isoforms $(\alpha, \beta$ and $\gamma)$ are a superfamily of nuclear receptors ${ }^{(148)}$. Fatty acids and lipid-derived substrates are their ligands. PPAR- $\gamma$ agonists are used as T2DM treatment drugs. PPAR- $\alpha$, present in liver, heart and skeletal muscle, promotes primarily hepatic fatty acid oxidation, ketone body synthesis and glucose sparing, while PPAR- $\gamma$, expressed in the lower intestine, adipose tissue and immunity cells, facilitates an increase in fatty acid storage in adipocytes ${ }^{(148)}$.

Thiazolidinediones (TZD) are strong activators of PPAR- $\gamma$ which improve insulin sensitivity and facilitate insulin-mediated suppression of gluconeogenesis in the liver and glucose uptake in the skeletal muscle ${ }^{(148,149)}$. However, PPAR- $\gamma$ is expressed in adipose tissues but not in muscle, the main insulin-sensitive tissue $^{(148)}$. Activation of PPAR- $\gamma$ causes release of adiponectin from mature adipocytes, which stimulates AMP involved in the up-regulation of glucose transporters (especially, GLUT4) in skeletal muscle, the stimulation of increased fatty acid oxidation in mitochondria ${ }^{(148)}$, as well as the down-regulation of gluconeogenesis in the liver ${ }^{(150)}$, consequently leading to improved insulin sensitivity in skeletal muscle ${ }^{(148)}$ and in the liver ${ }^{(149)}$. Metformin, a T2DM treatment medicine, is a stimulator of $\mathrm{AMPK}^{(148)}$. It is suggested that the combined use of PPAR ligands (for example, TZD) and SCFA could minimise weight gain from TZD releasing ANGPTL4 ${ }^{(151)}$.

\section{SCFA and intestinal gluconeogenesis}

One potential mechanism for SCFA to prevent T2DM involves intestinal gluconeogenesis (IGN) which is mediated by signalling of the periportal nervous system ${ }^{(152)}$. Hepatic gluconeogenesis and IGN play opposite roles in glucose homeostasis. IGN might be inversely associated with the risk of T2DM, as beneficial effects of IGN on a reduction in food intake, weight gain and hepatic glucose output, and on improvement in glycaemic control, have been shown ${ }^{(153-155)}$. In contrast, increased hepatic gluconeogenesis is related to the risk of T2DM ${ }^{(156,157)}$. The intestine produces approximately $20-25 \%$ of total endogenous glucose in the fasted state ${ }^{(158)}$. Glucose produced by the intestine is sent to the portal vein. The periportal neural system in the portal vein walls detects glucose and sends a signal to the brain for the modulation of energy and glucose metabolism ${ }^{(158)}$. Interestingly, butyrate directly promotes IGN gene expression in enterocytes by increasing intracellular cyclic AMP levels in an FFAR2-independent manner ${ }^{(152)}$. Propionate binding to FFAR3 present in the portal nerves increases IGN gene expression through a portal hypothalamic neural circuit ${ }^{(152)}$. The benefit of this gut-brain neural circuits has been shown for portal glucose sensing 


\section{Dietary synbiotic intervention}

$200 \mathrm{ml}$ of synbiotic shake containing $10^{8} \mathrm{CFU} / \mathrm{ml}$ Lactobacillus acidophilus, $10^{8} \mathrm{CFU} / \mathrm{ml}$ Bifidobacterium bifidum and $2 \mathrm{~g}$ FOS $v .200 \mathrm{ml}$ of the synbiotic shake without bacteria $14 \times 10^{\circ} \mathrm{CFU} /$ tablet of probiotic capsule containing seven viab
and freeze-dried strains of $L$. acidophilus $\left(2 \times 10^{9} \mathrm{CFU}\right)$, L. casei $\left(7 \times 10^{9} \mathrm{CFU}\right)$, L. rhamnosus $\left(1.5 \times 10^{9} \mathrm{CFU}\right)$, L. bulgaricus $\left(2 \times 10^{8} \mathrm{CFU}\right)$, B. breve $\left(2 \times 10^{10} \mathrm{CFU}\right)$, $B$. longum $\left(7 \times 10^{9} \mathrm{CFU}\right)$, Streptococcus thermophilus $\left(1.5 \times 10^{9} \mathrm{CFU}\right)$ and $100 \mathrm{mg}$ FOS $v$. placebo containing the same substance without bacteria . placebo containing the

Two tablets/d of $500 \mathrm{mg}$ metformin + two tablets/d of protexin CFU) CFU), L. bulgaricus $\left(1.5 \times 10^{8} \mathrm{CFU}\right)$, L. Thamnosus $\left(7.5 \times 10^{7}\right.$ thermophilus $\left(5 \times 10^{7} \times 10^{7}\right.$ ) ( 500 hilus $\left(5 \times 10^{7} \times 10^{7}\right.$ CFU), B. bre of $500 \mathrm{mg}$ metformin + two tablets/d of placebo $(120 \mathrm{mg}$ of

Two sachets/d of Lepicol containing $2 \times 10^{8} \mathrm{CFU}$ of strains of L. plantarum, L. delbrueckii ssp. bulgaricus, $L$. acidophilus, $L$. rhamnosus, B. bifidum and $3 \mathrm{~g} \mathrm{FOS} / \mathrm{d} v$. control (usual care)

Two tablets/d of protexin containing $2 \times 10^{8} \mathrm{CFU}$ of strains (L. casei, L. rhamnosus, Streptococcus thermophilus, $B$. breve, $L$. acidophilus, $B$. longum and $L$. bulgaricus) and $250 \mathrm{mg}$ FOS $v$. two tablets/d of placebo $(250 \mathrm{mg}$ maltodextrin)

Two tablets/d of protexin containing $2 \times 10^{8} \mathrm{CFU}$ of strains (L. casei, L. rhamnosus, S. thermophilus, B. breve, $L$. acidophilus, B. longum and $L$. bulgaricus) and $250 \mathrm{mg}$ FOS $v$. two tablets/d of placebo ( $250 \mathrm{mg}$ maltodextrin)

(a) $120 \mathrm{~g} / \mathrm{d}$ of synbiotic bread containing $L$ sporogenes $\left(1 \times 10^{\circ}\right.$ $\mathrm{CFU}$ ) and $0.07 \mathrm{~g}$ inulin as prebiotic per $1 \mathrm{~g}$

(b) Probiotic

(c) Control bread

Synbiotic food containing L. sporogenes $\left(27 \times 10^{7} \mathrm{CFU}\right)$ and $1.08 \mathrm{~g}$ inulin per $\mathrm{d} v$. control food (the same substance without probiotic bacteria and prebiotic inulin)

Synbiotic food containing $L$. sporogenes $\left(18 \times 10^{7} \mathrm{CFU}\right)$ and $0.72 \mathrm{~g}$ inulin per $\mathrm{d} v$. control food (the same substance without probiotic bacteria and prebiotic inulin)

(a) Synbiotic group $\left(4 \times 10^{9} \mathrm{CFU}\right.$ L. salivarius UBL S22 and $10 \mathrm{~g} / \mathrm{d}$ of FOS)

(b) probiotic $\left(4 \times 10^{9} \mathrm{CFU}\right.$ L. salivarius

(c) placebo capsule (gelatin)

Synbiotic capsule containing L. acidophilus $\left(2 \times 10^{9}\right.$, L. case

$2 \times 10^{9}$, B. bifidum $2 \times 10^{9} \mathrm{CFU} / \mathrm{g}$ and $800 \mathrm{mg}$ inulin

Two tablets/d of protexin containing $2 \times 10^{8} \mathrm{CFU}$ of strain

(L. casei, L. rhamnosus, S. thermophilus, B. breve

$L$. acidophilus, B. longum and L. bulgaricus) and $250 \mathrm{mg}$ FOS

$v$. two tablets/d of placebo ( $250 \mathrm{mg}$ maltodextrin)
Subjects

20 Adults with T2DM aged $50-60$ years, 10/group

54 Adults with T2DM aged $35-70$ years, 27 per group

63 Subjects with NASH

RD, DB, PC, P 24 weeks

20 Subjects with NASH OL, RD, C

26 weeks AAFLD

38 Subjects with the MetS

Design

period

Outcomes

No effects

TC, TAG

Reference

and $30 \mathrm{~d}$
ingestion

$\downarrow$ hs-CRP, $\uparrow$ GSH,$\downarrow$ fasting glucose

Fasting glucose, $\downarrow$ TAG

$\downarrow$ cholesterol, $\downarrow$ BMI, $\downarrow$ ALT,

Liver fat within the synbiotic group $v$. baseline 1 AST within and between groups

$\downarrow$ Fasting glucose, $\downarrow$ insulin, $\downarrow$ HOMA-IR, $\downarrow$ ALT, $\downarrow$ AST, $\downarrow$ GGT, $\downarrow$ hs-CRP, $\downarrow$ TNF- $a, \downarrow$ NF-KB

Fasting glucose, insulin and HOMA-IR, $\uparrow$ QUICKI within the treatment group $v$, baseline

\section{BMI, LDL-C, waist}

circumstance

$\downarrow$ Insulin, $\downarrow$ HOMA-IR, $\downarrow$ HOMA for Fasting glucose, QUICKI $\beta$-cell function, $\downarrow$ TAG, $\downarrow$ VLDL-C, $\downarrow \mathrm{TC}: \mathrm{HDL}-\mathrm{C}, \uparrow \mathrm{HDL}-\mathrm{C}, \uparrow \mathrm{NO}$ MDA v probiotic and control breads T2DM aged 35-70 group

62 Diabetic patients aged $35-70$ years

52 Pregnant women primigravida, aged third trimester

45 Healthy adults aged
$20-25$ years, $15 /$ group

60 Overweight diabetic patients with $\mathrm{CHD}$ aged $40-85$ years,

$30 /$ group
50 Lean subjects with $\quad R D D B, P C, P \quad 28$ weeks
$\mathrm{RD}, \mathrm{DB}, \mathrm{CO}, \mathrm{C} \quad 6$ weeks

RD, PC $\quad 9$ weeks

RD, PC, P, SB 6 weeks

RD DB, PC, P 12 week

RD DB, PC, P 28 weeks

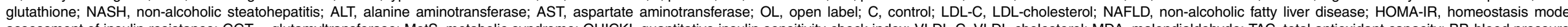

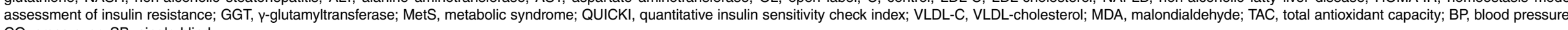
$\mathrm{CO}$, cross-over; SB, single blind. 
initiated by a protein-enriched diet, resulting in decreased food intake ${ }^{(154)}$.

IGN-deficient mice (with disruption of the glucose 6-phosphatase (G6Pase) catalytic subunit in the intestine) fed a SCFA- or FOS-rich diet showed no favourable effect on glucose and insulin with no change in body weight, compared with normal mice fed a SCFA- or FOS-rich diet ${ }^{(152)}$. Moreover, normal mice fed a high-fat/high-sucrose diet supplemented with FOS showed improved glucose and insulin tolerance and decreased fat mass, whereas these metabolic benefits were absent in IGN-deficient mice fed the same diet with FOS ${ }^{(152)}$. Therefore, IGN appears to be essential for the effect of SCFA on glucose homeostasis.

\section{Synbiotics and effects of synbiotics on glucose metabolism in human interventions}

A combination of probiotics and prebiotics is described as a synbiotic $^{(77)}$. Lactobacillus acidophilus DSM20079 induced 14.5-fold more butyrate in the presence of inulin or pectin than in the presence of glucose ${ }^{(159)}$.

Human interventions of synbiotics are shown in Table 3. Eleven of twelve studies of synbiotics have shown favourable effects on glucose metabolism ${ }^{(13,17,160-169)}$. Three ${ }^{(17,168,169)}$ of four $^{(17,167-169)}$ studies in subjects with non-alcoholic fatty liver disease have shown a positive effect on glucose control. The Asemi research group conducted a randomised, double-blind, placebo-controlled trial in subjects with T2DM; the consumption of synbiotic bread (containing the probiotic Lactobacillus sporogenes $\left(1 \times 10^{8} \mathrm{CFU}\right)$ and $0.07 \mathrm{~g}$ inulin per $1 \mathrm{~g}$ as prebiotic) for 8 weeks improved insulin metabolism, lipid profiles and plasma NO and malondialdehyde levels, compared with the probiotic alone (Lactobacillus sporogenes; $1 \times 10^{8} \mathrm{CFU}$ ) and a control bread ${ }^{(164,170,171)}$.

In summary, a very limited number of interventions have shown beneficial effects on glucose metabolism. More pronounced effects of synbiotics on glycaemic control and inflammation have been observed than with the use of probiotics alone ${ }^{(15)}$

\section{Conclusion}

Individuals with obesity or T2DM have been observed to have a different composition of gut microbiota. Altered gut microbiota may contribute to the development of T2DM. The composition of gut microbiota can be beneficially modified by probiotics and/or prebiotics to maintain glucose homeostasis. The potential mechanisms of action could involve insulinotropic and satiety effects mediated by gut hormones, GLP-1 and PYY, a $\beta$-cell-protective effect by reduced oxidative stress and lowered pro-inflammatory cytokines, anti-lipolytic activities and enhanced insulin sensitivity via GLUT4 through the upregulation of AMPK signalling in tissues. An additional role of SCFA is in glycaemic control through IGN and mediated by the periportal nervous system. The antidiabetic effects of SCFA require further research. Use of resistant starch and synbiotics may become a diabetic nutritional strategy. Overall human interventions of probiotic and prebiotics showed mixed findings, so further work is required.

\section{Acknowledgements}

P. M. C. is supported by a National Health and Medical Research Council (NHMRC) Principal Research Fellowship, University of South Australia. Y. A. K. is supported by an Australian Postgraduate Award.

All authors conceived of the manuscript structure and contributed to the writing and editing.

The authors have no conflicts of interest related to this paper.

\section{References}

1. Guariguata L, Whiting DR, Hambleton I, et al. (2014) Global estimates of diabetes prevalence for 2013 and projections for 2035. Diabetes Res Clin Pract 103, 137-149.

2. Sherwin RS, Anderson RM, Buse JB, et al. (2003) The prevention or delay of type 2 diabetes. Diabetes Care 26, S62-S69.

3. Nathan DM (1993) Long-term complications of diabetes mellitus. N Engl J Med 328, 1676-1685.

4. Backhed F, Ding H, Wang T, et al. (2004) The gut microbiota as an environmental factor that regulates fat storage. Proc Natl Acad Sci U S A 101, 15718-15723.

5. Rabot S, Membrez M, Bruneau A, et al. (2010) Germ-free C57BL/6J mice are resistant to high-fat-diet-induced insulin resistance and have altered cholesterol metabolism. FASEB J 24, 4948-4959.

6. Lindsay KL, Kennelly M, Culliton M, et al. (2014) Probiotics in obese pregnancy do not reduce maternal fasting glucose: a double-blind, placebo-controlled, randomized trial (Probiotics in Pregnancy Study). Am J Clin Nutr 99, 1432-1439.

7. Ley RE, Backhed F, Turnbaugh P, et al. (2005) Obesity alters gut microbial ecology. Proc Natl Acad Sci U S A 102, 11070-11075

8. Ley RE, Turnbaugh PJ, Klein S, et al. (2006) Microbial ecology: human gut microbes associated with obesity. Nature 444, 1022-1023.

9. Yadav H, Lee J-H, Lloyd J, et al. (2013) Beneficial metabolic effects of a probiotic via butyrate-induced GLP-1 hormone secretion. J Biol Chem 288, 25088-25097.

10. Ejtahed HS, Mohtadi-Nia J, Homayouni-Rad A, et al. (2012) Probiotic yogurt improves antioxidant status in type 2 diabetic patients. Nutrition 28, 539-543.

11. Yadav H, Jain S \& Sinha PR (2008) Oral administration of dahi containing probiotic Lactobacillus acidophilus and Lactobacillus casei delayed the progression of streptozotocin-induced diabetes in rats. J Dairy Res $\mathbf{7 5}$, 189-195.

12. Hove KD, Brons C, Faerch K, et al. (2015) Effects of 12 weeks of treatment with fermented milk on blood pressure, glucose metabolism and markers of cardiovascular risk in patients with type 2 diabetes: a randomised double-blind placebo-controlled study. Eur J Endocrinol 172, 11-20.

13. Tajabadi-Ebrahimi M, Sharifi N, Farrokhian A, et al. (2017) A randomized controlled clinical trial investigating the effect of synbiotic administration on markers of insulin metabolism and lipid profiles in overweight type 2 diabetic patients with coronary heart disease. Exp Clin Endocrinol Diabetes 125, 21-27.

14. Moreno-Indias I, Cardona F, Tinahones FJ, et al. (2014) Impact of the gut microbiota on the development of obesity and type 2 diabetes mellitus. Front Microbiol 5, 190. 
15. Jumpertz R, Le DS, Turnbaugh PJ, et al. (2011) Energybalance studies reveal associations between gut microbes, caloric load, and nutrient absorption in humans. Am J Clin Nutr 94, 58-65.

16. Turnbaugh PJ, Backhed F, Fulton L, et al. (2008) Dietinduced obesity is linked to marked but reversible alterations in the mouse distal gut microbiome. Cell Host Microbe 3, 213-223.

17. Shavakhi A, Minakari M, Firouzian H, et al. (2013) Effect of a probiotic and metformin on liver aminotransferases in non-alcoholic steatohepatitis: a double blind randomized clinical trial. Int J Prev Med 4, 531-537.

18. Turnbaugh PJ, Hamady M, Yatsunenko T, et al. (2009) A core gut microbiome in obese and lean twins. Nature $\mathbf{4 5 7}$, 480-484.

19. Turnbaugh PJ, Ley RE, Mahowald MA, et al. (2006) An obesity-associated gut microbiome with increased capacity for energy harvest. Nature 444, 1027-1131.

20. Larsen N, Vogensen FK, van den Berg FW, et al. (2010) Gut microbiota in human adults with type 2 diabetes differs from non-diabetic adults. PLOS ONE 5, e9085.

21. Wu X, Ma C, Han L, et al. (2010) Molecular characterisation of the faecal microbiota in patients with type II diabetes. Curr Microbiol 61, 69-78.

22. Qin J, Li Y, Cai Z, et al. (2012) A metagenome-wide association study of gut microbiota in type 2 diabetes. Nature 490, 55-60.

23. Everard A, Belzer C, Geurts L, et al. (2013) Cross-talk between Akkermansia muciniphila and intestinal epithelium controls diet-induced obesity. Proc Natl Acad Sci U S A 110, 9066-9071.

24. Shin NR, Lee JC, Lee HY, et al. (2014) An increase in the Akkermansia spp. population induced by metformin treatment improves glucose homeostasis in diet-induced obese mice. Gut $\mathbf{6 3}, 727-735$.

25. Org E, Parks BW, Joo JW, et al. (2015) Genetic and environmental control of host-gut microbiota interactions. Genome Res 25, 1558-1569.

26. Li J, Lin S, Vanhoutte PM, et al. (2016) Akkermansia muciniphila protects against atherosclerosis by preventing metabolic endotoxemia-induced inflammation in Apoe $e^{--}$mice. Circulation 133, 2434-2446.

27. Schneeberger M, Everard A, Gomez-Valades AG, et al. (2015) Akkermansia muciniphila inversely correlates with the onset of inflammation, altered adipose tissue metabolism and metabolic disorders during obesity in mice. Sci Rep 5, 16643.

28. Dao MC, Everard A, Aron-Wisnewsky J, et al. (2016) Akkermansia muciniphila and improved metabolic health during a dietary intervention in obesity: relationship with gut microbiome richness and ecology. Gut 65, 426-436.

29. Vrieze A, Van Nood E, Holleman F, et al. (2012) Transfer of intestinal microbiota from lean donors increases insulin sensitivity in individuals with metabolic syndrome. Gastroenterology 143, 913-916.e7.

30. Bäckhed F, Manchester JK, Semenkovich CF, et al. (2007) Mechanisms underlying the resistance to diet-induced obesity in germ-free mice. Proc Natl Acad Sci U S A 104, 979-984.

31. Cani PD, Amar J, Iglesias MA, et al. (2007) Metabolic endotoxemia initiates obesity and insulin resistance. Diabetes 56, 1761-1772.

32. Cani PD, Bibiloni R, Knauf C, et al. (2008) Changes in gut microbiota control metabolic endotoxemia-induced inflammation in high-fat diet-induced obesity and diabetes in mice. Diabetes 57, 1470-1481.
33. Wellen KE, Fucho R, Gregor MF, et al. (2007) Coordinated regulation of nutrient and inflammatory responses by STAMP2 is essential for metabolic homeostasis. Cell 129, 537-548.

34. Waki H \& Tontonoz P (2007) STAMPing out inflammation. Cell 129, 451-452.

35. Bouter KE, van Raalte DH, Groen AK, et al. (2017) Role of the gut microbiome in the pathogenesis of obesity and obesity-related metabolic dysfunction. Gastroenterology 152, 1671-1678.

36. Araya M, Morelli L, Reid G, et al. (2002) Guidelines for the evaluation of probiotics in food. Joint FAO/WHO Working Group Report on Drafting Guidelines for the Evaluation of Probiotics in Food, London, Ontario, Canada, April 30 and May 1, 2002. http://www.who.int/foodsafety/fs_manage ment/en/probiotic_guidelines.pdf

37. Homayoni Rad A, Mehrabany EV, Alipoor B, et al. (2012) Do probiotics act more efficiently in foods than in supplements? Nutrition 28, 733-736.

38. Champagne CP, Ross RP, Saarela M, et al. (2011) Recommendations for the viability assessment of probiotics as concentrated cultures and in food matrices. Int J Food Microbiol 149, 185-193.

39. Reid G (2008) Probiotics and prebiotics - progress and challenges. Int Dairy J 18, 969-975.

40. Saraf K, Shashikanth M, Priy T, et al. (2010) Probiotics do they have a role in medicine and dentistry? JAPI $\mathbf{5 8}$, 488-492.

41. Bermudez-Brito M, Plaza-Diaz J, Munoz-Quezada S, et al. (2012) Probiotic mechanisms of action. Ann Nutr Metab 61, 160-174.

42. Laitinen K, Poussa T \& Isolauri E (2009) Probiotics and dietary counselling contribute to glucose regulation during and after pregnancy: a randomised controlled trial. Br J Nutr 101, 1679-1687.

43. Andreasen AS, Larsen N, Pedersen-Skovsgaard T, et al. (2010) Effects of Lactobacillus acidophilus NCFM on insulin sensitivity and the systemic inflammatory response in human subjects. Br J Nutr 104, 1831-1838.

44. Mohamadshahi M, Veissi M, Haidari F, et al. (2014) Effects of probiotic yogurt consumption on inflammatory biomarkers in patients with type 2 diabetes. Bioimpacts $\mathbf{4}$, 83-88.

45. Asemi Z, Samimi M, Tabassi Z, et al. (2013) Effect of daily consumption of probiotic yoghurt on insulin resistance in pregnant women: a randomized controlled trial. Eur J Clin Nutr 67, 71-74.

46. Rajkumar H, Mahmood N, Kumar M, et al. (2014) Effect of probiotic (VSL $\# 3$ ) and omega-3 on lipid profile, insulin sensitivity, inflammatory markers, and gut colonization in overweight adults: a randomized, controlled trial. Mediators Inflamm 2014, 348959.

47. Ostadrahimi A, Taghizadeh A, Mobasseri M, et al. (2015) Effect of probiotic fermented milk (kefir) on glycemic control and lipid profile in type 2 diabetic patients: a randomized double-blind placebo-controlled clinical trial. Iran J Public Health 44, 228.

48. Karamali M, Dadkhah F, Sadrkhanlou M, et al. (2016) Effects of probiotic supplementation on glycaemic control and lipid profiles in gestational diabetes: a randomized, double-blind, placebo-controlled trial. Diabetes Metab $\mathbf{4 2}$, 234-241.

49. Barreto FM, Colado Simao AN, Morimoto HK, et al. (2014) Beneficial effects of Lactobacillus plantarum on glycemia and homocysteine levels in postmenopausal women with metabolic syndrome. Nutrition 30, 939-942. 
50. Naruszewicz M, Johansson ML, Zapolska-Downar D, et al. (2002) Effect of Lactobacillus plantarum 299v on cardiovascular disease risk factors in smokers. Am J Clin Nutr 76, $1249-1255$.

51. Xiao JZ, Kondo S, Takahashi N, et al. (2003) Effects of milk products fermented by Bifidobacterium longum on blood lipids in rats and healthy adult male volunteers. J Dairy Sci 86, 2452-2461.

52. Simons LA, Amansec SG \& Conway P (2006) Effect of Lactobacillus fermentum on serum lipids in subjects with elevated serum cholesterol. Nutr Metab Cardiovasc Dis 16, 531-535.

53. Jones ML, Martoni CJ, Di Pietro E, et al. (2012) Evaluation of clinical safety and tolerance of a Lactobacillus reuteri NCIMB 30242 supplement capsule: a randomized control trial. Regul Toxicol Pharmacol 63, 313-320.

54. Yousefinejad A, Mazloom Z \& Dabbaghmanesh MH (2013) Effect of probiotics on lipid profile, glycemic control, insulin action, oxidative stress, and inflammatory markers in patients with type 2 diabetes: a clinical trial. Iran J Med Sci 38, 38-43.

55. Jung SP, Lee KM, Kang JH, et al. (2013) Effect of Lactobacillus gasseri BNR17 on overweight and obese adults: a randomized, double-blind clinical trial. Korean J Fam Med 34, 80-89.

56. Sharafedtinov KK, Plotnikova OA, Alexeeva RI, et al. (2013) Hypocaloric diet supplemented with probiotic cheese improves body mass index and blood pressure indices of obese hypertensive patients - a randomized double-blind placebo-controlled pilot study. Nutr J 12, 138.

57. Gøbel RJ, Larsen N, Jakobsen M, et al. (2012) Probiotics to adolescents with obesity: effects on inflammation and metabolic syndrome. J Pediatr Gastroenterol Nutr 55, 673-678.

58. Ogawa A, Kadooka Y, Kato K, et al. (2014) Lactobacillus gasseri SBT2055 reduces postprandial and fasting serum non-esterified fatty acid levels in Japanese hypertriacylglycerolemic subjects. Lipids Health Dis 13, 36.

59. Ivey KL, Hodgson JM, Kerr DA, et al. (2014) The effects of probiotic bacteria on glycaemic control in overweight men and women: a randomised controlled trial. Eur J Clin Nutr 68, $447-452$.

60. Sanders ME \& Klaenhammer TR (2001) Invited review: the scientific basis of Lactobacillus acidophilus NCFM functionality as a probiotic. J Dairy Sci 84, 319-331.

61. Patra JK, Das G, Paramithiotis S, et al. (2016) Kimchi and other widely consumed traditional fermented foods of Korea: a review. Front Microbiol 7, 1493.

62. Kim EK, An SY, Lee MS, et al. (2011) Fermented kimchi reduces body weight and improves metabolic parameters in overweight and obese patients. Nutr Res 31, 436-443.

63. An SY, Lee MS, Jeon JY, et al. (2013) Beneficial effects of fresh and fermented kimchi in prediabetic individuals. Ann Nutr Metab 63, 111-119.

64. Han K, Bose S, Wang JH, et al. (2015) Contrasting effects of fresh and fermented kimchi consumption on gut microbiota composition and gene expression related to metabolic syndrome in obese Korean women. Mol Nutr Food Res 59 1004-1008.

65. Shin GH, Kang BC \& Jang DJ (2016) Metabolic pathways associated with kimchi, a traditional Korean food, based on in silico modeling of published data. Genomics Inform 14, 222-229.

66. Panwar H, Rashmi HM, Batish VK, et al. (2013) Probiotics as potential biotherapeutics in the management of type 2 diabetes - prospects and perspectives. Diabetes Metab Res Rev 29, 103-112.
67. Belenguer A, Duncan SH, Calder AG, et al. (2006) Two routes of metabolic cross-feeding between Bifidobacterium adolescentis and butyrate-producing anaerobes from the human gut. Appl Environ Microbiol 72, 3593-3599.

68. Drucker DJ \& Nauck MA (2006) The incretin system: glucagon-like peptide-1 receptor agonists and dipeptidyl peptidase- 4 inhibitors in type 2 diabetes. Lancet $\mathbf{3 6 8}$, 1696-1705.

69. Seeliger S, Janssen PH \& Schink B (2002) Energetics and kinetics of lactate fermentation to acetate and propionate via methylmalonyl-CoA or acrylyl-CoA. FEMS Microbiol Lett 211, 65-70.

70. Ma D, Forsythe P \& Bienenstock J (2004) Live Lactobacillus rhamnosus [corrected] is essential for the inhibitory effect on tumor necrosis factor $\alpha$-induced interleukin- 8 expression. Infect Immun 72, 5308-5314.

71. Paszti-Gere E, Szeker K, Csibrik-Nemeth E, et al. (2012) Metabolites of Lactobacillus plantarum 2142 prevent oxidative stress-induced overexpression of proinflammatory cytokines in IPEC-J2 cell line. Inflammation 35, 1487-1499.

72. Lambiase A, Bracci-Laudiero L, Bonini S, et al. (1997) Human CD4+ T cell clones produce and release nerve growth factor and express high-affinity nerve growth factor receptors. J Allergy Clin Immunol 100, 408-414.

73. Ma D, Wolvers D, Stanisz AM, et al. (2003) Interleukin-10 and nerve growth factor have reciprocal upregulatory effects on intestinal epithelial cells. Am J Physiol Regul Integr Comp Physiol 284, R1323-R1329.

74. Pierucci D, Cicconi S, Bonini P, et al. (2001) NGFwithdrawal induces apoptosis in pancreatic $\beta$ cells in vitro. Diabetologia 44, 1281-1295.

75. Yoo JY \& Kim SS (2016) Probiotics and prebiotics: present status and future perspectives on metabolic disorders. Nutrients 8, 173.

76. Gibson GR, Probert HM, Loo JV, et al. (2004) Dietary modulation of the human colonic microbiota: updating the concept of prebiotics. Nutr Res Rev 17, 259-275.

77. Flesch AG, Poziomyck AK \& Damin DC (2014) The therapeutic use of symbiotics. Arq Bras Cir Dig 27, 206-209.

78. Dehghan P, Pourghassem Gargari B \& Asghari Jafar-abadi M (2014) Oligofructose-enriched inulin improves some inflammatory markers and metabolic endotoxemia in women with type 2 diabetes mellitus: a randomized controlled clinical trial. Nutrition 30, 418-423.

79. Sanz Y \& Santacruz A (2010) Probiotics and prebiotics in metabolic disorders and obesity. In Bioactive Foods in Promoting Health: Probiotics and Prebiotics, , pp. 237-258 [RR Watson and VR Preedy, editors]. Boston, MA: Academic Press.

80. Jackson KG, Taylor GR, Clohessy AM, et al. (1999) The effect of the daily intake of inulin on fasting lipid, insulin and glucose concentrations in middle-aged men and women. Br J Nutr 82, 23-30.

81. Russo F, Riezzo G, Chiloiro M, et al. (2010) Metabolic effects of a diet with inulin-enriched pasta in healthy young volunteers. Curr Pharm Des 16, 825-831.

82. Cani PD, Lecourt E, Dewulf EM, et al. (2009) Gut microbiota fermentation of prebiotics increases satietogenic and incretin gut peptide production with consequences for appetite sensation and glucose response after a meal. Am J Clin Nutr 90, 1236-1243.

83. Brighenti F, Casiraghi M, Canzi E, et al. (1999) Effect of consumption of a ready-to-eat breakfast cereal containing inulin on the intestinal milieu and blood lipids in healthy male volunteers. Eur J Clin Nutr 53, 726-733. 
84. Letexier D, Diraison F \& Beylot M (2003) Addition of inulin to a moderately high-carbohydrate diet reduces hepatic lipogenesis and plasma triacylglycerol concentrations in humans. Am I Clin Nutr 77, 559-564.

85. Kok NN, Morgan LM, Williams CM, et al. (1998) Insulin, glucagon-like peptide 1, glucose-dependent insulinotropic polypeptide and insulin-like growth factor I as putative mediators of the hypolipidemic effect of oligofructose in rats. J Nutr 128, 1099-1103.

86. Everard A, Lazarevic V, Derrien M, et al. (2011) Responses of gut microbiota and glucose and lipid metabolism to prebiotics in genetic obese and diet-induced leptinresistant mice. Diabetes 60, 2775-2786.

87. Yamashita K, Kawai K \& Itakura M (1984) Effects of fructooligosaccharides on blood glucose and serum lipids in diabetic subjects. Nutr Res 4, 961-966.

88. Giacco R, Clemente G, Luongo D, et al. (2004) Effects of short-chain fructo-oligosaccharides on glucose and lipid metabolism in mild hypercholesterolaemic individuals. Clin Nutr 23, 331-340.

89. Luo J, Rizkalla SW, Alamowitch C, et al. (1996) Chronic consumption of short-chain fructooligosaccharides by healthy subjects decreased basal hepatic glucose production but had no effect on insulin-stimulated glucose metabolism. Am J Clin Nutr 63, 939-945.

90. Parnell JA \& Reimer RA (2009) Weight loss during oligofructose supplementation is associated with decreased ghrelin and increased peptide $\mathrm{YY}$ in overweight and obese adults. Am J Clin Nutr 89, 1751-1759.

91. Daubioul CA, Horsmans Y, Lambert P, et al. (2005) Effects of oligofructose on glucose and lipid metabolism in patients with nonalcoholic steatohepatitis: results of a pilot study. Eur I Clin Nutr 59, 723-726.

92. Genta S, Cabrera W, Habib N, et al. (2009) Yacon syrup: beneficial effects on obesity and insulin resistance in humans. Clin Nutr 28, 182-187.

93. Scheid MM, Genaro PS, Moreno YM, et al. (2014) Freezedried powdered yacon: effects of FOS on serum glucose, lipids and intestinal transit in the elderly. Eur J Nutr 53, $1457-1464$.

94. Alles MS, de Roos NM, Bakx JC, et al. (1999) Consumption of fructooligosaccharides does not favorably affect blood glucose and serum lipid concentrations in patients with type 2 diabetes. Am J Clin Nutr 69, 64-69.

95. Luo J, Van Yperselle M, Rizkalla SW, et al. (2000) Chronic consumption of short-chain fructooligosaccharides does not affect basal hepatic glucose production or insulin resistance in type 2 diabetics. $J$ Nutr 130, $1572-1577$.

96. Daud NM, Ismail NA, Thomas EL, et al. (2014) The impact of oligofructose on stimulation of gut hormones, appetite regulation and adiposity. Obesity 22, 1430-1438.

97. Tovar AR, Caamano Mdel C, Garcia-Padilla S, et al. (2012) The inclusion of a partial meal replacement with or without inulin to a calorie restricted diet contributes to reach recommended intakes of micronutrients and decrease plasma triglycerides: a randomized clinical trial in obese Mexican women. Nutr J 11, 44

98. Causey JL, Feirtag JM, Gallaher DD, et al. (2000) Effects of dietary inulin on serum lipids, blood glucose and the gastrointestinal environment in hypercholesterolemic men. Nutr Res 20, 191-201.

99. Dewulf EM, Cani PD, Claus SP, et al. (2013) Insight into the prebiotic concept: lessons from an exploratory, double blind intervention study with inulin-type fructans in obese women. Gut 62, 1112-1121.
100. Robertson MD, Bickerton AS, Dennis AL, et al. (2005) Insulin-sensitizing effects of dietary resistant starch and effects on skeletal muscle and adipose tissue metabolism. Am J Clin Nutr 82, 559-567.

101. Nilsson AC, Johansson-Boll EV \& Bjorck IM (2015) Increased gut hormones and insulin sensitivity index following a 3-d intervention with a barley kernel-based product: a randomised cross-over study in healthy middleaged subjects. Br J Nutr 114, 899-907.

102. Robertson MD, Currie JM, Morgan LM, et al. (2003) Prior short-term consumption of resistant starch enhances postprandial insulin sensitivity in healthy subjects. Diabetologia 46, 659-665.

103. Johnston KL, Thomas EL, Bell JD, et al. (2010) Resistant starch improves insulin sensitivity in metabolic syndrome. Diabet Med 27, 391-397.

104. Maki KC, Pelkman CL, Finocchiaro ET, et al. (2012) Resistant starch from high-amylose maize increases insulin sensitivity in overweight and obese men. $J$ Nutr 142, 717-723.

105. Bodinham CL, Smith L, Thomas EL, et al. (2014) Efficacy of increased resistant starch consumption in human type 2 diabetes. Endocr Connect 3, 75-84

106. Behall KM, Scholfield DJ, Hallfrisch JG, et al. (2006) Consumption of both resistant starch and $\beta$-glucan improves postprandial plasma glucose and insulin in women. Diabetes Care 29, 976-981.

107. Nichenametla SN, Weidauer LA, Wey HE, et al. (2014) Resistant starch type 4-enriched diet lowered blood cholesterols and improved body composition in a double blind controlled cross-over intervention. Mol Nutr Food Res 58, 1365-1369.

108. Costabile A, Klinder A, Fava F, et al. (2008) Whole-grain wheat breakfast cereal has a prebiotic effect on the human gut microbiota: a double-blind, placebo-controlled, crossover study. Br J Nutr 99, 110-120.

109. Cani PD, Possemiers S, Van de Wiele T, et al. (2009) Changes in gut microbiota control inflammation in obese mice through a mechanism involving GLP-2driven improvement of gut permeability. Gut 58, 1091-1103.

110. Woting A \& Blaut M (2016) The intestinal microbiota in metabolic disease. Nutrients $\mathbf{8}, 202$.

111. Dailey MJ \& Moran TH (2013) Glucagon-like peptide 1 and appetite. Trends Endocrinol Metab 24, 85-91.

112. Verdich C, Flint A, Gutzwiller JP, et al. (2001) A metaanalysis of the effect of glucagon-like peptide-1 (7-36) amide on ad libitum energy intake in humans. J Clin Endocrinol Metab 86, 4382-4389.

113. De Silva A \& Bloom SR (2012) Gut hormones and appetite control: a focus on PYY and GLP-1 as therapeutic targets in obesity. Gut Liver 6, 10-20.

114. Meier U \& Gressner AM (2004) Endocrine regulation of energy metabolism: review of pathobiochemical and clinical chemical aspects of leptin, ghrelin, adiponectin, and resistin. Clin Chem 50, 1511-1525.

115. Diamant M, Blaak E \& De Vos W (2011) Do nutrientgut-microbiota interactions play a role in human obesity, insulin resistance and type 2 diabetes? Obes Rev $\mathbf{1 2}$, 272-281.

116. Kaji I, Karaki S \& Kuwahara A (2014) Short-chain fatty acid receptor and its contribution to glucagon-like peptide-1 release. Digestion 89, 31-36.

117. Layden BT, Angueira AR, Brodsky M, et al. (2013) Short chain fatty acids and their receptors: new metabolic targets. Transl Res 161, 131-140. 
118. Lin HV, Frassetto A, Kowalik EJ Jr, et al. (2012) Butyrate and propionate protect against diet-induced obesity and regulate gut hormones via free fatty acid receptor 3-independent mechanisms. PLOS ONE 7, e35240.

119. Delzenne NM \& Cani PD (2011) Interaction between obesity and the gut microbiota: relevance in nutrition. Annu Rev Nutr 31, 15-31.

120. Cox MA, Jackson J, Stanton M, et al. (2009) Short-chain fatty acids act as antiinflammatory mediators by regulating prostaglandin $\mathrm{E}_{2}$ and cytokines. World J Gastroenterol 15 $5549-5557$.

121. Ge H, Li X, Weiszmann J, et al. (2008) Activation of G protein-coupled receptor 43 in adipocytes leads to inhibition of lipolysis and suppression of plasma free fatty acids. Endocrinology 149, 4519-4526.

122. Zaibi MS, Stocker CJ, O'Dowd J, et al. (2010) Roles of GPR41 and GPR43 in leptin secretory responses of murine adipocytes to short chain fatty acids. FEBS Lett 584, 2381-2386.

123. Dewulf EM, Cani PD, Neyrinck AM, et al. (2011) Inulin-type fructans with prebiotic properties counteract GPR43 overexpression and PPAR $\gamma$-related adipogenesis in the white adipose tissue of high-fat diet-fed mice. J Nutr Biochem 22, $712-722$

124. Abrams SA, Griffin IJ, Hawthorne KM, et al. (2007) Effect of prebiotic supplementation and calcium intake on body mass index. J Pediatr 151, 293-298.

125. Vinolo MA, Rodrigues HG, Hatanaka E, et al. (2011) Suppressive effect of short-chain fatty acids on production of proinflammatory mediators by neutrophils. J Nutr Biochem 22, 849-855.

126. Tedelind S, Westberg F, Kjerrulf M, et al. (2007) Antiinflammatory properties of the short-chain fatty acids acetate and propionate: a study with relevance to inflammatory bowel disease. World J Gastroenterol 13, 2826-2832

127. Liu T, Li J, Liu Y, et al. (2012) Short-chain fatty acids suppress lipopolysaccharide-induced production of nitric oxide and proinflammatory cytokines through inhibition of NF- $\kappa$ B pathway in RAW264.7 cells. Inflammation 35, 1676-1684.

128. Park JS, Lee EJ, Lee JC, et al. (2007) Anti-inflammatory effects of short chain fatty acids in IFN- $\gamma$-stimulated RAW 264.7 murine macrophage cells: involvement of NF- $\mathrm{KB}$ and ERK signaling pathways. Int Immunopharmacol 7, 70-77.

129. De Caterina R, Libby P, Peng HB, et al. (1995) Nitric oxide decreases cytokine-induced endothelial activation. Nitric oxide selectively reduces endothelial expression of adhesion molecules and proinflammatory cytokines. $J$ Clin Invest 96, 60-68.

130. Moncada S \& Higgs A (1993) The L-arginine-nitric oxide pathway. N Engl J Med 329, 2002-2012.

131. Murohara T, Asahara T, Silver M, et al. (1998) Nitric oxide synthase modulates angiogenesis in response to tissue ischemia. J Clin Invest 101, 2567-2578.

132. Rudic RD, Shesely EG, Maeda N, et al. (1998) Direct evidence for the importance of endothelium-derived nitric oxide in vascular remodeling. J Clin Invest 101, 731-736.

133. Sharma JN, Al-Omran A \& Parvathy SS (2007) Role of nitric oxide in inflammatory diseases. Inflammopharmacology 15, 252-259.

134. Usami M, Kishimoto K, Ohata A, et al. (2008) Butyrate and trichostatin A attenuate nuclear factor $\kappa \mathrm{B}$ activation and tumor necrosis factor $\alpha$ secretion and increase prostaglandin $\mathrm{E}_{2}$ secretion in human peripheral blood mononuclear cells. Nutr Res 28, 321-328.
135. Park GY, Joo M, Pedchenko T, et al. (2004) Regulation of macrophage cyclooxygenase- 2 gene expression by modifications of histone H3. Am J Physiol Lung Cell Mol Physiol 286, L956-L962.

136. Zapolska-Downar D, Siennicka A, Kaczmarczyk M, et al. (2004) Butyrate inhibits cytokine-induced VCAM-1 and ICAM-1 expression in cultured endothelial cells: the role of NF-кB and PPAR $\alpha$. J Nutr Biochem 15, 220-228.

137. Menzel T, Luhrs H, Zirlik S, et al. (2004) Butyrate inhibits leukocyte adhesion to endothelial cells via modulation of VCAM-1. Inflamm Bowel Dis 10, 122-128.

138. Zapolska-Downar D \& Naruszewicz M (2009) Propionate reduces the cytokine-induced VCAM-1 and ICAM-1 expression by inhibiting nuclear factor- $\mathrm{KB}(\mathrm{NF}-\kappa \mathrm{B})$ activation. J Physiol Pharmacol 60, 123-131.

139. Bohmig GA, Krieger PM, Saemann MD, et al. (1997) $n$-Butyrate downregulates the stimulatory function of peripheral blood-derived antigen-presenting cells: a potential mechanism for modulating T-cell responses by short-chain fatty acids. Immunology $\mathbf{9 2}, 234-243$.

140. Alex S, Lichtenstein L, Dijk W, et al. (2014) ANGPTL4 is produced by entero-endocrine cells in the human intestinal tract. Histochem Cell Biol 141, 383-391.

141. Köster A, Chao YB, Mosior M, et al. (2005) Transgenic angiopoietin-like (Angptl)4 overexpression and targeted disruption of Angptl4 and Angptl3: regulation of triglyceride metabolism. Endocrinology 146, 4943-4950.

142. Dewey FE, Gusarova V, O'Dushlaine C, et al. (2016) Inactivating variants in ANGPTL4 and risk of coronary artery disease. $N$ Engl J Med 374, 1123-1133.

143. Xu A, Lam MC, Chan KW, et al. (2005) Angiopoietin-like protein 4 decreases blood glucose and improves glucose tolerance but induces hyperlipidemia and hepatic steatosis in mice. Proc Natl Acad Sci U S A 102, 6086-6091.

144. Lichtenstein L, Mattijssen F, de Wit NJ, et al. (2010) Angptl4 protects against severe proinflammatory effects of saturated fat by inhibiting fatty acid uptake into mesenteric lymph node macrophages. Cell Metab 12, 580-592.

145. Georgiadi A, Lichtenstein L, Degenhardt T, et al. (2010) Induction of cardiac Angptl4 by dietary fatty acids is mediated by peroxisome proliferator-activated receptor $\beta / \delta$ and protects against fatty acid-induced oxidative stress. Circ Res 106, 1712-1721.

146. Demigné C, Morand C, Levrat M-A, et al. (1995) Effect of propionate on fatty acid and cholesterol synthesis and on acetate metabolism in isolated rat hepatocytes. Br J Nutr 74, 209-219.

147. Grootaert C, Van de Wiele T, Van Roosbroeck I, et al. (2011) Bacterial monocultures, propionate, butyrate and $\mathrm{H}_{2} \mathrm{O}_{2}$ modulate the expression, secretion and structure of the fasting-induced adipose factor in gut epithelial cell lines. Environ Microbiol 13, 1778-1789.

148. Ferré P (2004) The biology of peroxisome proliferatoractivated receptors relationship with lipid metabolism and insulin sensitivity. Diabetes 53, S43-S50.

149. Bouskila M, Pajvani U \& Scherer P (2005) Adiponectin: a relevant player in PPAR $\gamma$-agonist-mediated improvements in hepatic insulin sensitivity? Int J Obes 29, S17-S23.

150. Rutter GA, Da Silva Xavier G \& Leclerc I (2003) Roles of 5'-AMP-activated protein kinase (AMPK) in mammalian glucose homoeostasis. Biochem J 375, 1-16.

151. Korecka A, De Wouters T, Cultrone A, et al. (2013) ANGPTL4 expression induced by butyrate and rosiglitazone in human intestinal epithelial cells utilizes independent pathways. Am J Physiol Gastrointest Liver Physiol 304, G1025-G1037. 
152. De Vadder F, Kovatcheva-Datchary P, Goncalves D, et al. (2014) Microbiota-generated metabolites promote metabolic benefits via gut-brain neural circuits. Cell 156, 84-96.

153. Troy S, Soty M, Ribeiro L, et al. (2008) Intestinal gluconeogenesis is a key factor for early metabolic changes after gastric bypass but not after gastric lap-band in mice. Cell Metab 8, 201-211.

154. Mithieux G, Misery P, Magnan C, et al. (2005) Portal sensing of intestinal gluconeogenesis is a mechanistic link in the diminution of food intake induced by diet protein. Cell Metab 2, 321-329.

155. Gautier-Stein A, Zitoun C, Lalli E, et al. (2006) Transcriptional regulation of the glucose-6-phosphatase gene by cAMP/vasoactive intestinal peptide in the intestine. Role of HNF $4 \alpha$, CREM, HNF1 $\alpha$, and C/EBP $\alpha . J$ Biol Chem 281, 31268-31278.

156. DeFronzo R (1992) Pathogenesis of type 2 (non-insulin dependent) diabetes mellitus: a balanced overview. Diabetologia 35, 389-397.

157. Magnusson I, Rothman D, Katz L, et al. (1992) Increased rate of gluconeogenesis in type II diabetes mellitus. ${ }^{13} \mathrm{C}$ nuclear magnetic resonance study. J Clin Invest 90, 1323.

158. Mithieux G (2014) Nutrient control of energy homeostasis via gut-brain neural circuits. Neuroendocrinology 100, 89-94.

159. Nazzaro F, Fratianni F, Nicolaus B, et al. (2012) The prebiotic source influences the growth, biochemical features and survival under simulated gastrointestinal conditions of the probiotic Lactobacillus acidophilus. Anaerobe 18, 280-285.

160. Moroti C, Souza Magri LF, de Rezende Costa M, et al. (2012) Effect of the consumption of a new symbiotic shake on glycemia and cholesterol levels in elderly people with type 2 diabetes mellitus. Lipids Health Dis 11, 29.

161. Asemi Z, Zare Z, Shakeri H, et al. (2013) Effect of multispecies probiotic supplements on metabolic profiles, hs-CRP, and oxidative stress in patients with type 2 diabetes. Ann Nutr Metab 63, 1-9.

162. Rajkumar H, Kumar M, Das N, et al. (2015) Effect of probiotic Lactobacillus salivarius UBL S22 and prebiotic fructo-oligosaccharide on serum lipids, inflammatory markers, insulin sensitivity, and gut bacteria in healthy young volunteers: a randomized controlled single-blind pilot study. J Cardiovasc Pharmacol Ther 20, 289-298.

163. Eslamparast T, Zamani F, Hekmatdoost A, et al. (2014) Effects of synbiotic supplementation on insulin resistance in subjects with the metabolic syndrome: a randomised, double-blind, placebo-controlled pilot study. BrJ Nutr 112, 438-445.

164. Tajadadi-Ebrahimi M, Bahmani F, Shakeri H, et al. (2014) Effects of daily consumption of synbiotic bread on insulin metabolism and serum high-sensitivity C-reactive protein among diabetic patients: a double-blind, randomized, controlled clinical trial. Ann Nutr Metab 65, 34-41.

165. Asemi Z, Khorrami-Rad A, Alizadeh SA, et al. (2014) Effects of synbiotic food consumption on metabolic status of diabetic patients: a double-blind randomized cross-over controlled clinical trial. Clin Nutr 33, 198-203.

166. Taghizadeh M \& Asemi Z (2014) Effects of synbiotic food consumption on glycemic status and serum hs-CRP in pregnant women: a randomized controlled clinical trial. Hormones (Athens) 13, 398-406.

167. Wong VW, Won GL, Chim AM, et al. (2013) Treatment of nonalcoholic steatohepatitis with probiotics. A proof-ofconcept study. Ann Hepatol 12, 256-262.

168. Eslamparast T, Poustchi H, Zamani F, et al. (2014) Synbiotic supplementation in nonalcoholic fatty liver disease: a randomized, double-blind, placebo-controlled pilot study. Am J Clin Nutr 99, 535-542.

169. Mofidi F, Poustchi H, Yari Z, et al. (2017) Synbiotic supplementation in lean patients with non-alcoholic fatty liver disease: a pilot, randomised, double-blind, placebocontrolled, clinical trial. Br J Nutr 117, 662-668.

170. Bahmani F, Tajadadi-Ebrahimi M, Kolahdooz F, et al. (2016) The consumption of synbiotic bread containing Lactobacillus sporogenes and inulin affects nitric oxide and malondialdehyde in patients with type 2 diabetes mellitus: randomized, double-blind, placebo-controlled trial. J Am Coll Nutr 35, 506-513.

171. Shakeri H, Hadaegh $\mathrm{H}$, Abedi F, et al. (2014) Consumption of synbiotic bread decreases triacylglycerol and VLDL levels while increasing HDL levels in serum from patients with type-2 diabetes. Lipids 49, 695-701. 